\title{
VIVIENDA SOCIAL LATINOAMERICANA: LA CLONACIÓN DEL PAISAJE DE LA EXCLUSIÓN
}

\author{
Rodríguez Chumillas, Isabel \\ isabel.rodriguez@uam.es \\ Dra. Geógrafa, Profesora Titular de Análisis Geográfico Regional \\ Universidad Autónoma de Madrid \\ Ctra. Colmenar Viejo, Km. 15, 5 \\ 28049 Madrid, España \\ Remisión inicial: 13-9-2006 Remisión definitiva: 25-9-2006
}

Palabras Clave: vivienda social, grandes promociones inmobiliarias, urbanismo cerrado, paisajes de exclusión.

Resumen: Las grandes capitales cómo Ciudad de México, Santiago de Chile, o Bogotá amplían desproporcionadamente sus periferias metropolitanas con megaproyectos residenciales de gran superficie y elevado número de viviendas. Se trata de la producción masiva de vivienda barata. El artículo registra e interpreta estos cambios en la producción de vivienda, enfatizando el papel de los promotores inmobiliarios y el protagonismo del urbanismo cerrado que se ha extendido también a los grupos sociales de menores ingresos bajo distintas fórmulas jurídico-urbanísticas entre las que destaca el condominio.

Hoy proliferan en las ciudades de Latinoamérica, y en particular en las fronterizas con Estados Unidos, las calles cerradas y las casas sin pasillo, porque la vivienda social deficiente en tamaño, diseño y calidades, se traduce en una morfología cerrada que explicita la generalización de unos modos de habitar que sugieren una mayor especialización y una nueva configuración socioespacial del territorio, de paisajes y arquitecturas de la exclusión.

\section{La perspectiva de estudio.}

El envite de las nuevas condiciones espacio-temporales también repercute directamente en las características que toma la vivienda social en Latinoamérica. En distintas ciudades latinoamericanas como México- D.F., Bogotá y Santiago de Chile destaca, entre las nuevas tendencias urbanas, el diseño de un urbanismo cerrado de sociabilidad interrumpida, incluso para la oferta de vivienda social. La práctica privada de producir y organizar los nuevos espacios fragmentariamente, por proyectos, constituyen los rasgos del modelo del urbanismo cerrado expresivo de la ciudad contemporánea ${ }^{1}$.

Particularmente desde la geografía, la economía, la historia, la sociología y la arquitectura, de dónde ha partido una línea tradicional de explicaciones en este sentido, se contextualizan las etapas del plano y del territorio urbano, con la evolución de la sociedad y la economía urbana en sus manifestaciones formales. Se ha hecho a partir del reconocimiento y definición de ámbitos "periféricos" que se apoyan en el análisis de los ciclos de la edificación residencial, la

\footnotetext{
${ }^{1}$ A través del estudio de las formas espaciales, entendidas como soporte metodológico (Vilagrasa, 1991), se observa el protagonismo de la lógica empresarial en las respuestas sociales a los retos de la ciudad contemporánea.
} 
renta y el mercado del suelo, el comportamiento y protagonismo de los agentes, la importancia de la propiedad como definidora de formas y la distribución y papel de los usos del suelo. Más específicamente, los análisis internos de las expresiones urbanas, ciudades y regiones metropolitanas, se abordan con una amplia perspectiva histórica en la que las funciones del espacio se observan condicionadas por los actores y las políticas urbanas, convirtiéndose en elementos comprensivos, el planeamiento y la propiedad y promoción inmobiliaria. Así, el énfasis de los estudios ha recaído sobre los grupos, estructuras y mecanismos que componen el sistema inmobiliario que interviene en las distintas etapas del crecimiento urbano y que se concreta en la producción diferenciada de formas urbanas.

En tal sentido, estas megaoperaciones individualizadas, tendentes al aislamiento y al encerramiento, aportan nuevas dimensiones de la problemática actual de la ciudad latinoamericana porque concreta las características recientes que ha tomado la política de la vivienda pública y el papel del sector inmobiliario. Entre las cuestiones fundamentales de este nuevo entendimiento del problema de la necesidad y calidad de la vivienda, los promotores públicos y privados están aplicando un imaginario común materializado en un producto de corte nítidamente fordista y el discurso global del estilo de vida de la élite, del encerramiento. Utilizando los argumentos forjados en la férrea cadena de miedo, uniendo los eslabones de la pobreza, la inmigración y ambos con la criminalidad, con la simulación y el consumo, arman un nuevo producto o modelo de vivienda social como alternativa a la informalidad y marginalidad de la vivienda espontánea.

Desde el arranque del nuevo milenio se ha incrementado notablemente la producción de ciudad, formal y conceptualmente, cerrada, compuesta de viviendas de tamaños cuestionablemente pequeños. El urbanismo defensivo ${ }^{2}$ ha llegado a ser dominante tanto en su distribución espacial en la ciudad como dentro del sector inmobiliario, y concretamente en el más dinámico, el que ha introducido en la mayoría de las ciudades latinoamericanas más profesionalización en el sector de la construcción y la promoción residencial, constituyéndose en la oferta mayoritaria ${ }^{3}$. La vivienda social resultante suma numerosas deficiencias. A las evidentes consecuencias negativas que arrastra una superficie tan pequeña $\left(30 \mathrm{~m}^{2}\right)$, sobre todo por aplicar el modelo invariablemente sin considerar el tamaño y las necesidades del núcleo familiar, se suman otras características también deficientes de calidades de los materiales, diseño, terminaciones, etc., que hacen de la vivienda en condominios, básicamente cerrados, un nuevo producto inmobiliario, la vivienda social del siglo XXI, claramente precario desde varios puntos de vista.

En el escenario local de la frontera noroeste de México dónde se profundizará en los casos de Tijuana, Nogales y Ciudad Juárez, la urbanización cerrada de los condominios horizontales de interés social, exacerba el sello híbrido y complejo de los paisajes urbanos fronterizos. A partir de estas grandes promociones masivas de vivienda barata se están produciendo desmesurados crecimientos de fuerte inercia en la construcción del territorio, y de su artificio urbano. Crece una nueva Tijuana, una nueva Nogales y una nueva Ciudad Juárez en las planicies y los cerros. Supone la multiplicación de vecindarios defensivos que amplían la ambivalencia de los paisajes fronterizos, refuerzan los antagonismos con la imagen y vida urbana de deshecho de las barrancas y cañadas. Según el tamaño de la ciudad se gana en

\footnotetext{
${ }^{2}$ Aunque su proliferación las ha hecho ubicuas (Méndez-Rodríguez, 2004).

${ }^{3}$ En esta u otras versiones de urbanismo cerrado (Cabrales, 2005).
} 
complejidad y, de este modo, la dualidad entre lo formal y lo informal es mucho más clara, la yuxtaposición de los vecindarios defensivos alcanza a ámbitos espaciales y sociales muy heterogéneos, y la clonación de minihogares a crédito involucra una ingente cantidad de suelo, personas, tamaños, modalidades, etc. No obstante, Nogales ofrece un escenario minimalista extraordinariamente útil por la simplicidad y pureza de los procesos emergentes ${ }^{4}$. En estos casos de las ciudades fronterizas, la demanda social -de exclusión- en boga y la fragmentación territorial, se ven como efectos de una política pública deficiente que auspicia la empresarial.

La pertinencia de la investigación y del ámbito de análisis son importantes para el estudio de la vivienda social en Latinoamérica por la agudización de los problemas del alojamiento que experimentan estas ciudades, y la singularidad de este espacio fronterizo, primero, por su escala latinoamericana, y por contener a las ciudades gemelas norteamericanas, al otro lado de la Línea internacional. Es posible que ello haya influido en la propia "invención" del modelo, y desde luego, en su puesta en práctica y aplicación masiva que ha posibilitado el perfeccionamiento del producto y de sus productoras las inmobiliarias norteñas.

\section{La vivienda social ante las nuevas condiciones que operan en la construcción de la ciudad.}

La hipótesis que se baraja es que la reducción de distancias y, con ella, la desaparición de los límites, provoca en el espacio una comunión de las relaciones sociales que genera incertidumbre existencial. Las nuevas condiciones espacio-temporales se asimilan, entonces, construyendo nuevas formas cerradas de hábitat que garanticen la seguridad del status quo combatiendo los efectos negativos de la globalización. Simulan eliminar la comunión citada en las relaciones socio-espaciales.

Con la reducción de distancias que la globalización ha introducido como efecto final de la fulminante disminución del tiempo, se ha construido un nuevo tipo de expansión territorial con formas de ocupación del suelo difusas, y en general, nuevas formas de consumirlo involucrando siempre mucho territorio (Figura $N^{\circ} 1$ ). Son nuevos usos del suelo según el tipo de propietario y las funciones específicas que les asignan en las emergentes relaciones espacio-temporales de la contemporaneidad. Para enfrentarse a ellas se está construyendo y justificando la necesidad de fijar límites (nuevas fronteras en el espacio y la refortificación de otros límites).

\footnotetext{
${ }^{4}$ Rodríguez, 2005b.
} 
Figura $\mathrm{N}^{\circ}$ 1: Muros y bardas que simulan eliminar la comunión en las relaciones socioespaciales.

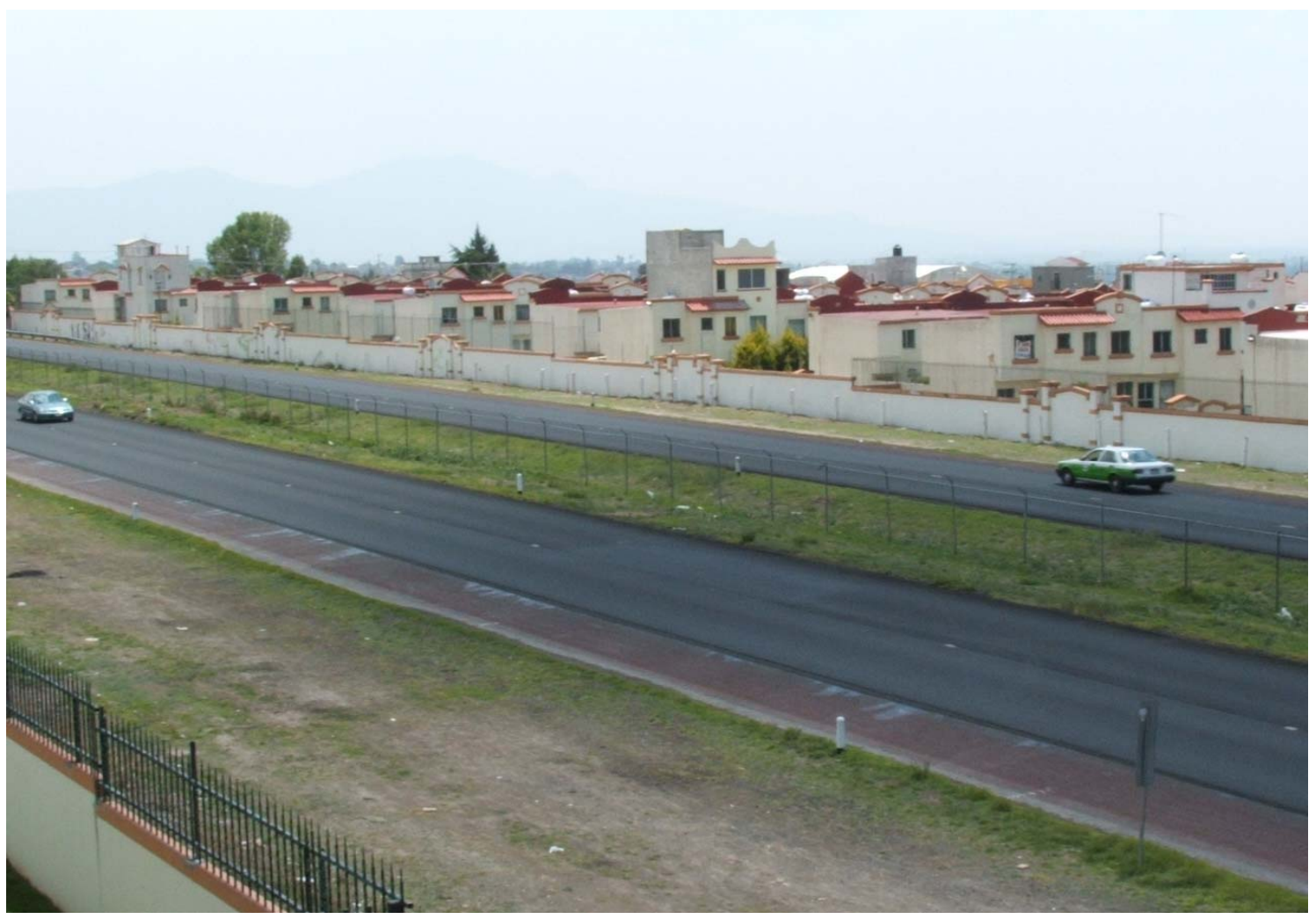

Fuente: Zona metropolitana norte de México, 2006. Fotografía de la autora.

También determina que las interrelaciones entre los elementos del territorio, mayoritariamente permanentes, dispersos, cerrados y privados, y la necesidad de cruzarlos defina una circulación continua en un nuevo espacio operativo. La organización territorial traduce estas nuevas relaciones a través de la fragmentación espacial en una dualidad novedosa por la especialización del espacio privado y el público.

El espacio privado se concentra territorialmente al tiempo que se unifica por categorías socioeconómicas. El último tiende a ser sólo espacio operativo que se simplifica y especializa, perdiendo su papel de único espacio fijo y permanente de interrelación social. Por una parte, la aparición de espacios privados y cerrados, dónde se cualifica el "espacio público" (de propiedad privada comunitaria), se desarrolla al tiempo que el espacio público colectivo (y el resto de servicios e infraestructuras urbanas de la ciudad) mantiene unas fuertes deficiencias de conservación o es inexistente. Además, la continuidad y conectividad física que da razón de ser al espacio público se ha roto y se ha especializado en sus funciones hacia un uso efímero, sólo de paso entre los lugares. De este modo, se simplifica, se especializa y sólo se materializa en elementos de cambiante movilidad (le confieren una permanente condición efímera). Un espacio público que así pierde una de sus finalidades básicas cómo es la de espacio común y tradicional, es decir, se relega su papel de único espacio fijo y permanente de interrelación social. En definitiva, se ha exacerbado su condición de transmisor en detrimento de otras 
cualidades y, en consecuencia, se ha habilitado su estructura y su artificio hacia una condición de espacio transitorio ${ }^{5}$, función que sobre especializa el espacio público ${ }^{6}$ y le confiere un importante papel en la configuración de un nuevo tipo de expansión del territorio. Hay, por tanto, nuevos procesos espacio-temporales, efímeros y fugaces, que necesitarían ser analizados ${ }^{7}$.

\section{Figura $\mathrm{N}^{\circ}$ 2: Formas cerradas de hábitat. Vecindario defensivo de Comunidades} Brasa.

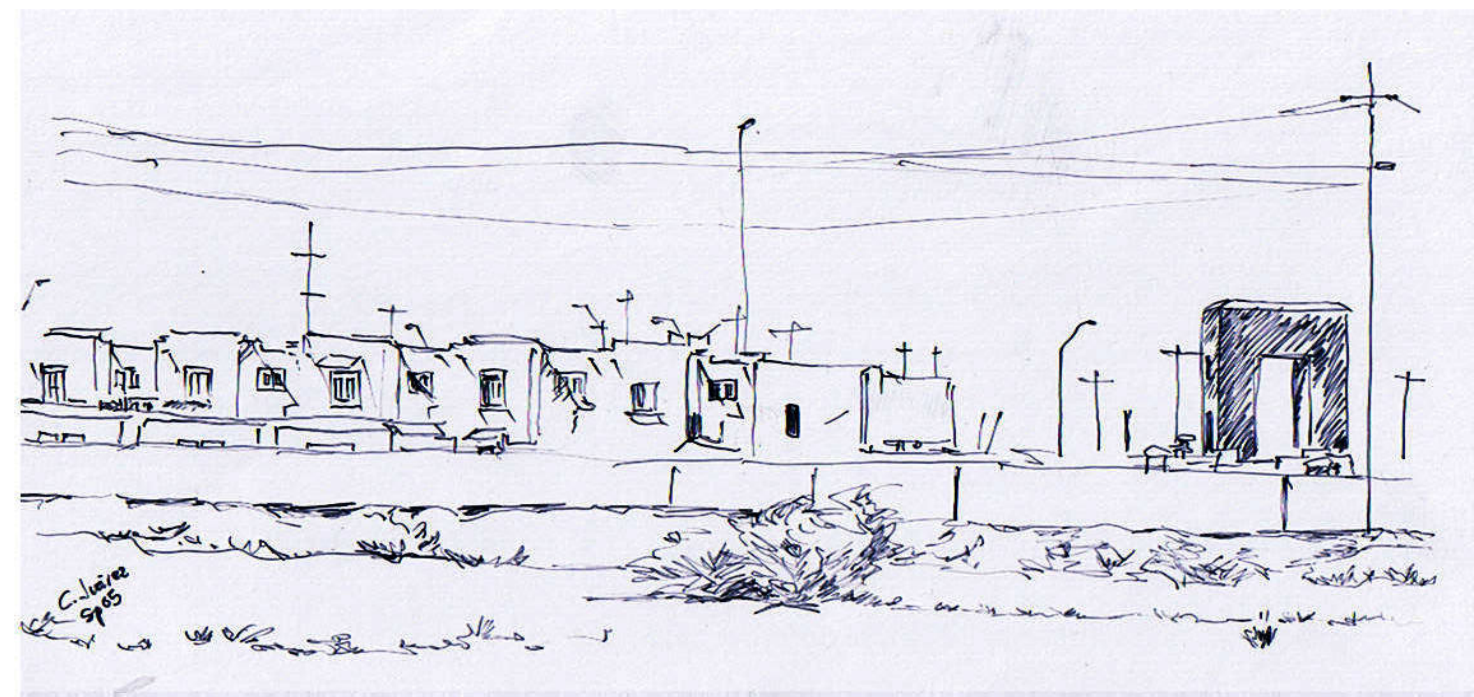

Fuente: Ciudad Juárez, México, 2005. Fotos de la autora.

Por lo anterior, por la singular circunstancia de una reducción de distancias, y con ella la desaparición de los límites, hay en el espacio una comunión en las relaciones sociales que produce incertidumbre y por ello vulnerabilidad. Se trata de un vértigo "socioagorafóbico" que está actuando cómo factor modelador del territorio entre las nuevas condiciones que operan en su construcción. Actúa para contrarrestar la reducción de la distancia en el nuevo espacio construyendo y justificando la necesidad de fijar límites con elementos permanentes y

\footnotetext{
${ }^{5}$ El principal soporte de prácticas que implican movilidad, principalmente, desde la casa, nodo aún central, y que imprimen una imagen veloz en el paisaje para desaparecer inmediatamente (Hiernaux, 2002).

\begin{abstract}
${ }^{6}$ Muestra la aparición de un nuevo paisaje, híbrido, una forma distinta de paisaje integrado resultante del continuo e intempestivo cruce de los sujetos en el paisaje tradicional, es decir, interactuando en la movilidad del territorio, cruzándolo, usándolo como espacio operativo para una apropiación eficaz y rápida, sin apreciarlo, sin participar de él, sólo consumirlo en el período más corto de tiempo y a través del trayecto espacial más corto. Esa fugacidad es una nueva forma de consumo de espacios y actividades y, en consecuencia, puede ser demandada y satisfecha, es una dimensión invisible del espacio que expresa la lógica cultural de ciertos componentes del paisaje que no se leen a primera vista (Hiernaux. 2002, 15).

${ }^{7}$ Se considera que estos paisajes híbridos pueden identificarse cómo una nueva categoría de paisaje metropolitano, en el sentido más arriba apuntado, de exacerbación de su condición de transmisor y, por tanto, su carácter de espacio transitorio. Cuándo la importancia de estos en el territorio es notable y ordena el territorio, se sugiere asignar la denominación de "paisajes de frontera" cómo una nueva categoría para definir la prioridad lineal de un espacio de flujo, un espacio para el movimiento, efímero y fugaz, que la ciudad difusa engendra y que configura paisajes híbridos
\end{abstract} permanentemente efímeros con cambios continuos del límite.
} 
privados $^{8}$. Límites cambiantes en el espacio público operativo y límites fijos en el espacio privado $^{9}$ (Figura No 2).

Las nuevas condiciones espacio-temporales se asimilan entonces, construyendo nuevas formas cerradas de hábitat con el objeto de combatir los efectos negativos de la globalización ${ }^{10}$. Los nuevos límites en el espacio, se concretan en muros y bardas que simulan eliminar la comunión citada en las relaciones socioespaciales. Se simula el control de una parte del territorio mediante la separación física del espacio, creando un espacio interno de control privado y un espacio exterior. Un "afuera" de carácter operativo, sin límites y de indefinida incertidumbre.

En las grandes ciudades latinoamericanas, el territorio fuera de control es la inevitable tramoya que ha impuesto el drama de la inmigración. Así, con el continuo flujo de inmigrantes queda garantizada, por una parte, la necesidad creciente de alojamiento barato que sólo encuentra acomodo en invasiones ${ }^{11}$. Por otra parte, se genera la presencia de "el otro", pieza maestra en el tablero inmobiliario fronterizo, que permite manejar la pertinencia de los vecindarios defensivos como una necesidad y orientar su demanda social. Estas nuevas condiciones también están operando en la frontera noroeste de México; en sus ciudades tanto la Línea internacional cómo las líneas de las bardas de los vecindarios defensivos son permanente penetrados, son límites siempre tenues, frágiles, porosos ${ }^{12}$ dónde el crecimiento urbano, acelerado y desordenado, ha construido un deficiente espacio físico que hace más explícitas las respuestas empresariales y sociales que se generan a favor de la reconquista de parte de esos espacios, los que han quedado fuera del control económico y social hegemónico. Su yuxtaposición con los límites permanentes que imponen los vecindarios defensivos, con el límite mismo de la Línea internacional -refortificado-, conforma nuevos paisajes que se conforman para marcar el fin de la comunicación física y, por tanto, indican expresivamente la falta de cohesión social.

\footnotetext{
${ }^{8}$ También se puede enunciar esta segunda hipótesis considerando que, precisamente, la percepción del carácter limitado del planeta, ha determinado la exacerbación de la separación para garantizar lo privado. Así, el muro evidencia la yuxtaposición entre el adentro y el afuera, precisamente, porque no lo hay, requiere explicitarse, materializarse, constituir el punto de concreción para naturalizar el límite y que se familiarice la sociedad con la incomunicación, o con la diferencia, la distinción, lo otro.

${ }^{9}$ Cabría entonces argumentar que ahora que la distancia ya no es una defensa, tampoco es una defensa la que pone la distancia del muro porque además, el territorio pierde importancia y ya no hay afuera.

${ }^{10}$ La socioagorafobia sugiere otras vertientes a contemplar cómo respuesta generalizada de encierro individual frente al miedo social por las condiciones imperantes. El vecino encerrado, autoexcluido del "afuera" adverso, por más motivaciones colindantes con la señalada, representa el retraimiento social ante el vértigo de la movilidad del tiempo. El encierro así, supone un ensimismamiento, un retraerse sobre sí mismo del individuo para enfrentar a solas la adversidad de un mundo hostil, produciéndose la paradoja del sin sentido del individuo sin su sociedad.

${ }^{11}$ La mayor parte de las nuevas periferias en las ciudades fronterizas del noroeste, en efecto, han sido ocupadas a través de invasiones de predios privados durante las dos últimas décadas con frecuencia cómo "auto-invasiones": una ocupación ilegal del suelo propiciada por los propietarios para vender suelo evadiendo los costos de urbanización, a corto plazo, y buscando su regularización para la consecuente revalorización de los terrenos adyacentes, en el medio plazo.
}

${ }^{12}$ En el sentido de que las fronteras son móviles pues no hay alianzas duraderas, ni colonos que cumplan los acuerdos, o que los incumplen antes de que se firmen, redefiniendo constantemente el límite que separa a los aliados de los enemigos (Bauman, 2004, 24), "más bien, participarían coaliciones flotantes de países, sujetas al cambio y a la evolución" (28). También son tenues y frágiles los límites de los conjuntos residenciales de baja densidad que tiene más que ver con el tiempo y el espacio social, que con el propio espacio físico de la urbanización cerrada, pese al carácter hermético. 
Igual que en otros momentos del proceso de construcción del territorio, la construcción de nuevos límites en el espacio urbano se somete a los mecanismos tradicionales de producción e inversión inmobiliaria que asume y reinterpreta las demandas recientes de exclusión social ofreciendo, dentro de su permanente renovación, nuevos productos resultantes de variaciones en los modos y formas de vida exitosos y, por tanto, rentables. Estos presupuestos son los que sitúan esta interpretación en una línea metodológica propia al insertar la vivienda social dentro del contexto actual determinado por los cambios en concreción de los modos de habitar. Los paisajes clonados como materialización de unas demandas sociales mediatizadas por las nuevas condiciones en las que actores y procesos de la producción de vivienda han modificado sus objetivos.

Desde la perspectiva del geógrafo especializado en el análisis urbano y, más concretamente, en el estudio pormenorizado de la producción material de la ciudad, se enfatizan las reflexiones sobre la territorialidad del mercado para priorizar el análisis desde la dimensión espacial que suele quedar marginada en los estudios económicos y estadísticos más clásicos, a pesar de su relevancia. La perspectiva de su consideración histórica en esta línea metodológica permite afirmar que a pesar de muchos ropajes nuevos, la esencia del mercado inmobiliario, en lo fundamental, no ha cambiado mucho en la construcción de las ciudades, que llevan funcionando con criterios de lucro capitalista desde muy temprano ${ }^{13}$.

De todo el rico panorama que el negocio inmobiliario contiene destacan algunas singularidades, novedosas y de importancia estructural. Así, el creciente papel del sector financiero en el negocio urbano, que según los países y contextos ha ido reorientándose hacia determinados productos y funciones, o las permanencias y cambios de las sociedades inmobiliarias como principales agentes productores.

Una constatación inevitable es la participación creciente del sector financiero en el mercado inmobiliario y, en general, en todo el negocio inmobiliario. El recurso financiero es casi obligado entre los promotores y los consumidores finales, por lo que las propias contabilidades hipotecarias forman parte ya de las estadísticas inmobiliarias ${ }^{14}$. El sector financiero, además, está muy interesado en el mercado de las hipotecas, por su estabilidad, pero se hecha en falta estudios en Latinoamérica que aborden estas cuestiones, dada la trascendencia socio-territorial de su actuación en la construcción y ordenación del territorio en la actualidad ${ }^{15}$. La experiencia

\footnotetext{
${ }^{13}$ La complejidad de su estudio y los intentos de establecer una clasificación de las inmobiliarias permiten constatar la repetición de unos esquemas que permiten comprender este mundo empresarial de gran protagonismo territorial, pero que no configuran una tipología definitiva y clara. De hecho, no existen clasificaciones lo suficientemente profundas acerca de las inmobiliarias. Los acercamientos realizados sobre el sector han perfilado esbozos utilizando alguno de los criterios como el de la procedencia del capital, pero se muestran igualmente parciales. Cabe destacar un ensayo, fundamentalmente de desarrollo teórico, sobre los tipos de promotores inmobiliarios en la línea de C. Topalov (1974). Para el caso de México las investigaciones de Marta Schteingart (1978, 1982, 1983, 1984, 1987 y 1989, en especial 1983: "La promoción inmobiliaria en el Área Metropolitana de México 1960-1980").

${ }^{14}$ Especialmente en el contexto español, el llamo segundo boom de ventas de los últimos 90s, el papel del precio del dinero ha sido clave. La progresiva unificación monetaria de la Unión Europea se ha traducido en unas tasas de interés reducida que animan a los agentes al endeudamiento, de un modo especial a los usuarios finales, que se animan a la compra ante unos desembolsos no muy diferentes entre el pago de un alquiler y el abono de las cuotas mensuales de un crédito hipotecario (Mas-Rodríguez, 2003).

${ }^{15}$ No hay más que leer las memorias de los bancos y cajas de ahorro para comprobar la importancia creciente de las hipotecas en sus balances. Los que ellos denominan créditos de garantía real alcanzan una proporción significativa del negocio bancario. En una entidad no especializada, como el Banco Central Hispano, el crédito hipotecario alcanzaba en 1997 el 21, 65 \% de su inversión crediticia, mientras que en una entidad más especializada, la antigua Argentaria, en el año 1994 ya se registraba el 35,3 \% (Mas-Rodríguez, 2003).
} 
local ha confirmado que es antigua la relación de las mayores sociedades inmobiliarias con los bancos, a nivel accionarial, pero ahora la interconexión es general. La banca entró ya en las fases de gestión del suelo y en la construcción, y en el objetivo final de succionar los compradores futuros subrogándose en sus créditos hipotecarios. Y una manera muy sencilla de captar el crédito hipotecario fue y es aumentando la promoción propia de viviendas.

Esta es la etapa que está aconteciendo, febrilmente, en las ciudades de Latinoamérica desde la última década del pasado siglo, y esta era la vía tradicional de actuación de las principales y más antiguas entidades financieras, las cajas de ahorro, como han demostrado estudios territoriales concretos en España. Ahora es una vía generalizada. Además, el precio de los préstamos hipotecarios es uno de los pocos elementos del mercado que no presenta variaciones geográficas en el sentido ya señalado (Mas y Rodríguez, 2003) por algunos especialistas en análisis de vivienda que indican el funcionamiento sincrónico de los mercados inmobiliarios en los países desarrollados desde mediados de los años ochenta, en paralelo a la reducción de la intervención directa de los gobiernos a la vez que se tiende a una regulación pura del a través del mercado financiero, mediante los tipos de interés. En Latinoamérica, cabría sugerir que la nueva política de la vivienda apunta en esta dirección.

Otra constatación y reflexión es la que se refiere a la progresiva importancia de un producto especializado del mercado inmobiliario, en el caso de Latinoamérica es la nueva vivienda social que se promueve en sus ciudades. El tema ha recibido atención desde diversas ópticas ${ }^{16}$, pero todavía claramente insuficientes, pese a que hay diversas perspectivas de acercamiento que ya inciden en la importancia del tema, cómo un ajuste estructural asociado a la globalización, y el desafío que representa por la agudización de sus efectos desde los años noventa: "Enfrentamos a partir de ello, problemas de nuevo tipo, que esencialmente sitúa la cuestión en las ciudades, tales como los cambios e las relaciones de mercado, los cambios sociodemográficos, los cambios culturales de habitar, nuevas formas de pobreza, etc. Es un proceso que tiene lugar en una ciudad a medio construir" (García Vázquez, 2005). Falta, sin embargo, la perspectiva del urbanismo cerrado que aquí se defiende y teoriza enfáticamente y que constituye una línea de trabajo que promete arrojar más luz sobre las circunstancias actuales $^{17}$, y que por el momento sólo ha sido enfrentada como una respuesta de clases altas que extiende por las medias desde los ochenta (Figura $N^{0} 3$ ). La aplicación de la misma lectura a estos nuevos megadesarrollos inmobiliarios de vivienda social, revalida al urbanismo cerrado como tendencia estructural de los cambios recientes, protagonizando las nuevas configuraciones que toma la ordenación y construcción de nuestros territorios urbanizados hoy (Figura $\mathrm{N}^{\circ} 4$ ).

\section{La producción masiva de ciudad cerrada cómo síntoma de cambios estructurales.}

La producción de vivienda social masivamente por el capital inmobiliario es un hecho de gran trascendencia en la sociedad latinoamericana. Nuevos y clónicos desarrollos residenciales de diseño cerrado se programan masivamente con apoyo del crédito en versiones populares. De modo que ahora la casa apropiada del estilo de vida ideal se aparea

\footnotetext{
${ }^{16}$ Es ilustrativo de la atención al tema y sus visiones diferentes los libros coordinados por Green, 2005 y MayaCervantes, 2005.

${ }_{17}$ Paradójicamente la naturalización del cierre en las ciudades latinoamericanas está incidiendo en la visión de éste cómo un elemento "común" del orden espacial, y por tanto, desviando la atención hacia evidencias como la mala calidad de la vivienda y condiciones de habitabilidad que, lamentablemente, acompaña inexorablemente la oferta de vivienda barata históricamente.
} 
en módulos de edificaciones o es adosada a la interminable hilera de iguales, cuando no se agrupa en tres, cuatro y cinco unidades. Todas, variantes de la producción masiva indiferenciada pero consumida y ofrecida dentro del discurso del nuevo estilo de vida del encierro, empaquetada con los símbolos de la seguridad.

Figura $N^{\circ}$ 3: Conjunto de vivienda social cerrada.

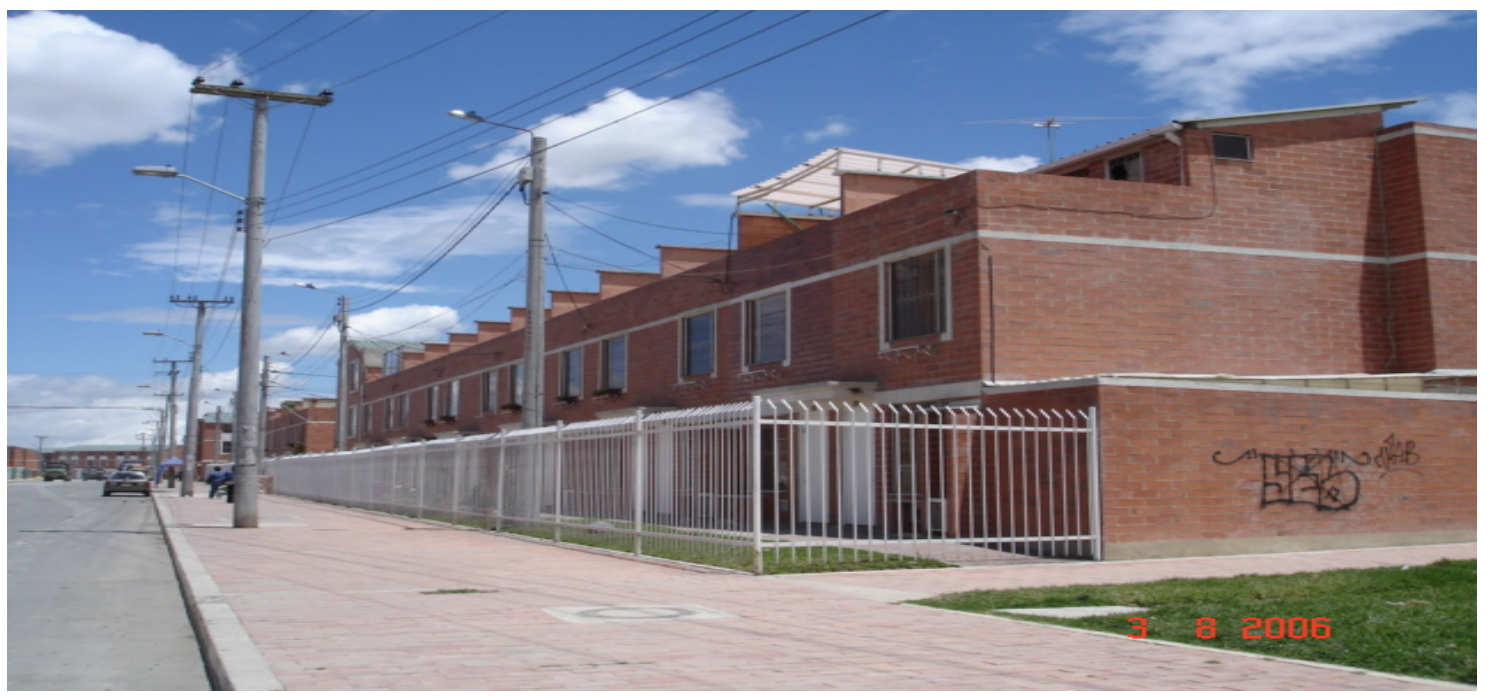

Fuente: Bogotá, Colombia, 2006. Fotografía del sector poniente de Bosa. Jenny Real de la Pontificia Universidad Javeriana de Bogotá.

Los modos de nombrar e identificar el producto definen las múltiples variantes del estilo de vida del encierro popular clasificadas en función de las distintas categorías socioeconómicas y culturales, pero sobre todo, las diferentes opciones resultan de la holgura económica que el crédito posibilita a los destinatarios potenciales y que tienen milimétrica y económicamente muy bien estudiados los equipos técnicos de las grandes inmobiliarias productoras ${ }^{18}$.

El sello inequívoco del interés social se reconoce en los intensivos aprovechamientos del suelo y en las seriadas disposiciones en hileras. Por eso, la opción, estilo arquitectónico, formas y tamaños, con todo y pese a ello, muestran la unidad del producto y su destino social de clase media-baja, mediante la repetición del mismo modelo de casa o los idénticos cierres traseros de las unidades que contornean sus clónicos y pequeños patios. Su propia homogeneidad formal muestra los procesos de selección social que han operado. Forman, a su vez, clónicas islas de viviendas en la periferia extensa y difusa que constituyen el elemento clave, notoriamente recurrente en las periferias de las ciudades del mundo, junto con los centros comerciales, de los ingredientes definitorios de los hinterland extensivos en los modelos de ciudad compacta en descomposición por las tendencias suburbanas.

El producto inmobiliario-urbano de "cerrada popular" es un esperpéntico resultado de la mezcla del ideario del Nuevo Urbanismo con la arquitectura moderna, es una formulación que recoge

\footnotetext{
${ }^{18}$ Cómo Urbi, Ara y CasasGeo entre las más grandes inmobiliarias del país con un gran volumen de negocio en más de una ciudad.
} 


\section{Figura $N^{\circ}$ 4: Comunidades cerradas en el Sector de Otay.}

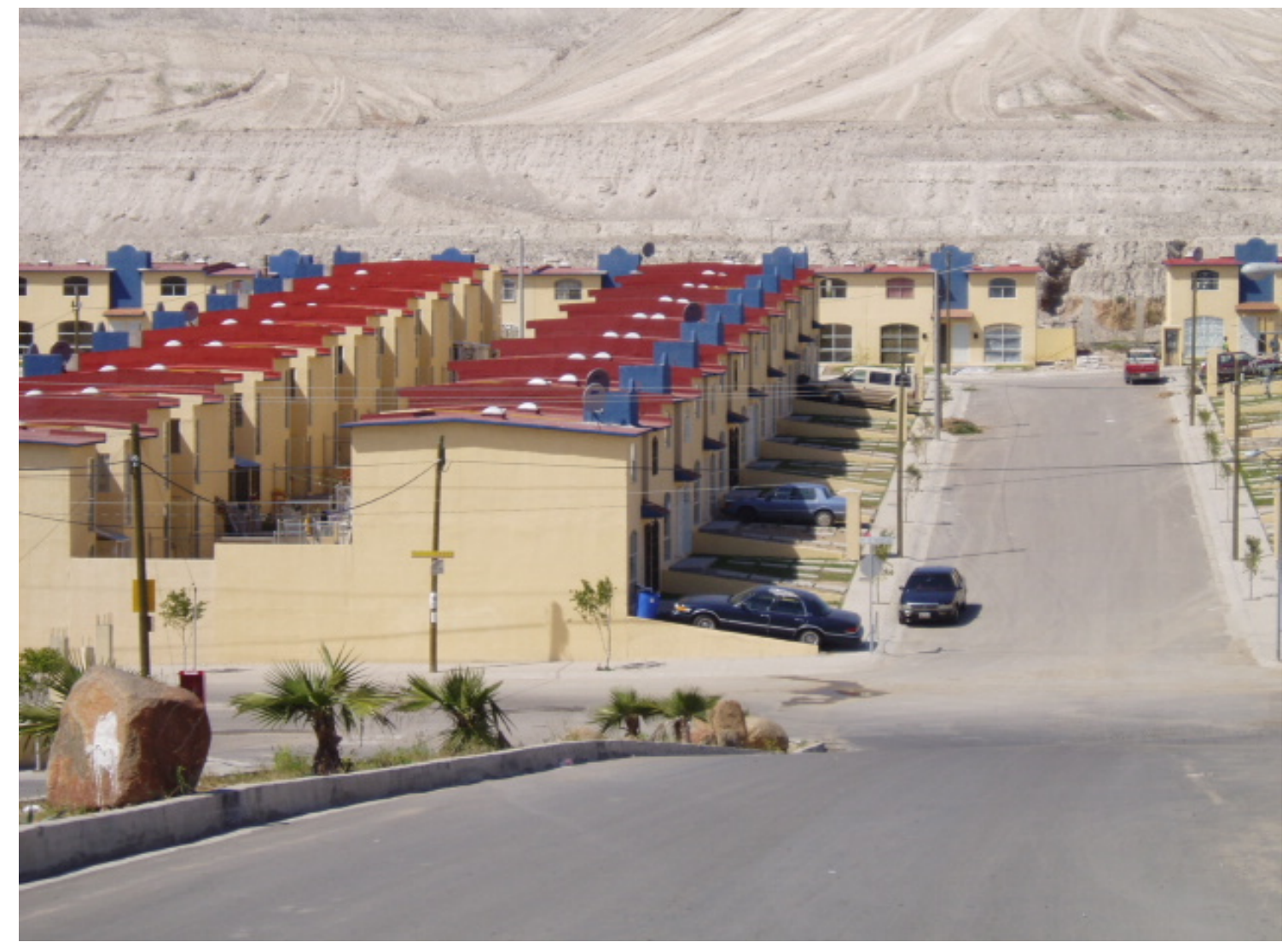

Fuente: Tijuana, Baja California, 2005. Fotografía del Equipo del Archivo de Comunidades cercadas.

en los clichés simbólicos del Nuevo Urbanismo expresados en evidencias de hermetismo antifuncional, principalmente, a través del cierre con el muro al objeto de forzar un nuevo producto con ambas influencias ${ }^{19}$. La reproducción clónica de modelos seriados del funcionalismo se encaja en el espacio para un nuevo orden social y urbano. La delimitación es requisito para la separación del resto y el nuevo ideario ${ }^{20}$. Ahora también, a diferencia de otras ocasiones en las que se intentó, la producción de conjuntos de casas idénticas para clases medias-bajas sí resulta una modalidad competitiva porque han cambiado las condiciones generales de producción de la economía y del sistema financiero y también el deseo y gustos de la sociedad (Figura № 5).

\footnotetext{
${ }^{19}$ Las cerradas populares mantienen a la perfección la deontología de la arquitectura moderna. No han abandonado el principio del funcionalismo y la reproducción clónica, al contrario, es una exacerbación individualizada de sus principios más toscos. La búsqueda de las formas operativas a las prácticas y necesidades sociales con el horizonte abierto por la ciudad-negocio, se reorientan a suministrar las series de elementos acoplados a moldes funcionales. La arquitectura buscaba deshacerse de todo artificio para universalizarse y rendirse a la riqueza, naturalidad y acciones impredecibles de los hombres.

${ }^{20}$ La producción en serie de vivienda unifamiliar es algo, por otra parte, nada original. Sin embargo, su combinación con el lenguaje y las finalidades del urbanismo en comunidad cerrada resulta novedosa, o al menos, su mensaje más elemental: la aceptación social del cierre.
} 
Se analizan las nuevas condiciones de la producción de vivienda en un contexto de cambio de la vivienda por cambio en las necesidades y apenas se han aportan interpretaciones desde el análisis de la oferta inmobiliaria. Desde la sociología se ha identificado el papel de los productores alimentados por estos cambios sociales, encontrándose que la oferta inmobiliaria ha respondido cuando esas condiciones estaban presentes. Se han interpretado (Bourdieu, 2000) como la vía de homogeneización social, desde el punto de vista de la estructura del capital. La adquisición de su vivienda, una inversión de primer orden, ha entrado gracias al crédito y a las subvenciones públicas, dentro de la lógica de la acumulación de un patrimonio económico que se ha entronizado cómo pieza clave del capital cultural ${ }^{21}$.

La aparición de modelos parecidos en el mercado muestra prácticas de producción masiva bien experimentadas por ventajosas, por reducir costos en la estandarización pero, sobre todo, por ampliar mercado. Esta emergencia, casi eclosión simultánea, de similares ofertas inmobiliarias denota tanto la vigilancia y plagio de nuevos productos entre empresas competidoras, como las estrategias empresariales de reacción ante el retraimiento o ralentización del mercado, al objeto de conquistar con nuevos productos más categorías sociales. Nuevos productos cerrados para las categorías sociales medias-bajas, y bajas, incluyendo la vivienda social, dentro de los esquemas de la vivienda clonada y cerrada. Las empresas de promoción inmobiliaria, locales y nacionales, intentan hacerse con un mercado en expansión, sostenido en las nuevas condiciones del sistema financiero de subvención y de crédito. En la actualidad se consigue presentar como innovadores productos a los que se ha aplicado la fórmula del urbanismo clónico y las formas cerradas. Son los productos capaces de competir con mayor éxito en el mercado ${ }^{22}$ y se utilizan para "detonar" nuevas áreas, en el sentido señalado.

No es nuevo ninguno de estos procesos y respuestas, ni en la asimilación de los cambios de los gustos y modas sobre la habitación, ni en las respuestas masivas, ni siquiera en la configuración de los diseños de la casa y la morfología de los espacios urbanos resultantes. En España, la larga tradición en vivienda social, ya veterana por su experiencia más que centenaria, y la emergencia de ella en distintos momentos de su historia urbana, son un importante referente de comparaciones y aprendizaje para la vivienda social latinoamericana (Hidalgo, 2004). Sólo dos apuntes para encontrar la reacción masiva del capital, financiero, industrial e inmobiliario, además del patrimonial, en la producción masiva de vivienda en las grandes ciudades españolas entre 1955-1975. El primero, la presencia de nuevo de los mismos dos elementos claves, el consenso de colaboración del Estado y el capital financiero para ayudar a ser solventes a los inmigrantes y convertirlos en demanda potencial para ser los futuros residentes. El segundo, el producto que construye espacios que configuran un paisaje de masividad y clonación. Desde diseños de vivienda social diametralmente opuestos en el sentido de densidades y ordenaciones, comparten sin embargo, la multiplicación de las unidades en partes de conjuntos de desproporcionadas dimensiones.

Ambos, en el pasado como en la actualidad, y aún en contextos tan diferentes, tienen un denominador común en las condiciones de inversión inmobiliaria que simplifica la comprensión de los procesos en estudio y también explica la magnitud de las operaciones (Figura $N^{\circ} 4$ ). Son grandes operadores urbanos cuya naturaleza es la de agentes privados profesionalizados que

\footnotetext{
${ }^{21}$ Bourdieu, 2000, 55.

22 Bourdieu, 2000, 92.
} 
producen masivamente un modelo en general de bajo costo, dimensiones mínimas y alta densidad y grado de ocupación del suelo.

En las ciudades latinoamericanas se asume una política de la vivienda cuyo modelo es la producción masiva de vivienda barata por la iniciativa privada. El caso colombiano es representativo de este cambio y dispone de especialistas que no sólo lo indagan sino que precisamente encuentran que la falta de reflexión sobre el diseño de la vivienda dirigida a los sectores sociales de bajos ingresos ha sido decisiva en la imposición de un esquema adoptado desde 1991 para la producción de vivienda de bajo costo (Figura № 5): "en el cual el Estado asume una forma de operación orientada desde la perspectiva del subsidio a la demanda basada en mecanismos de mercado, cambiando así su papel de promotor a facilitador de la oferta y la demanda" (Tarchópulos, 2000, 195).

Figura $\mathrm{N}^{\circ}$ 5: Microvivenda en torres, cerrada.

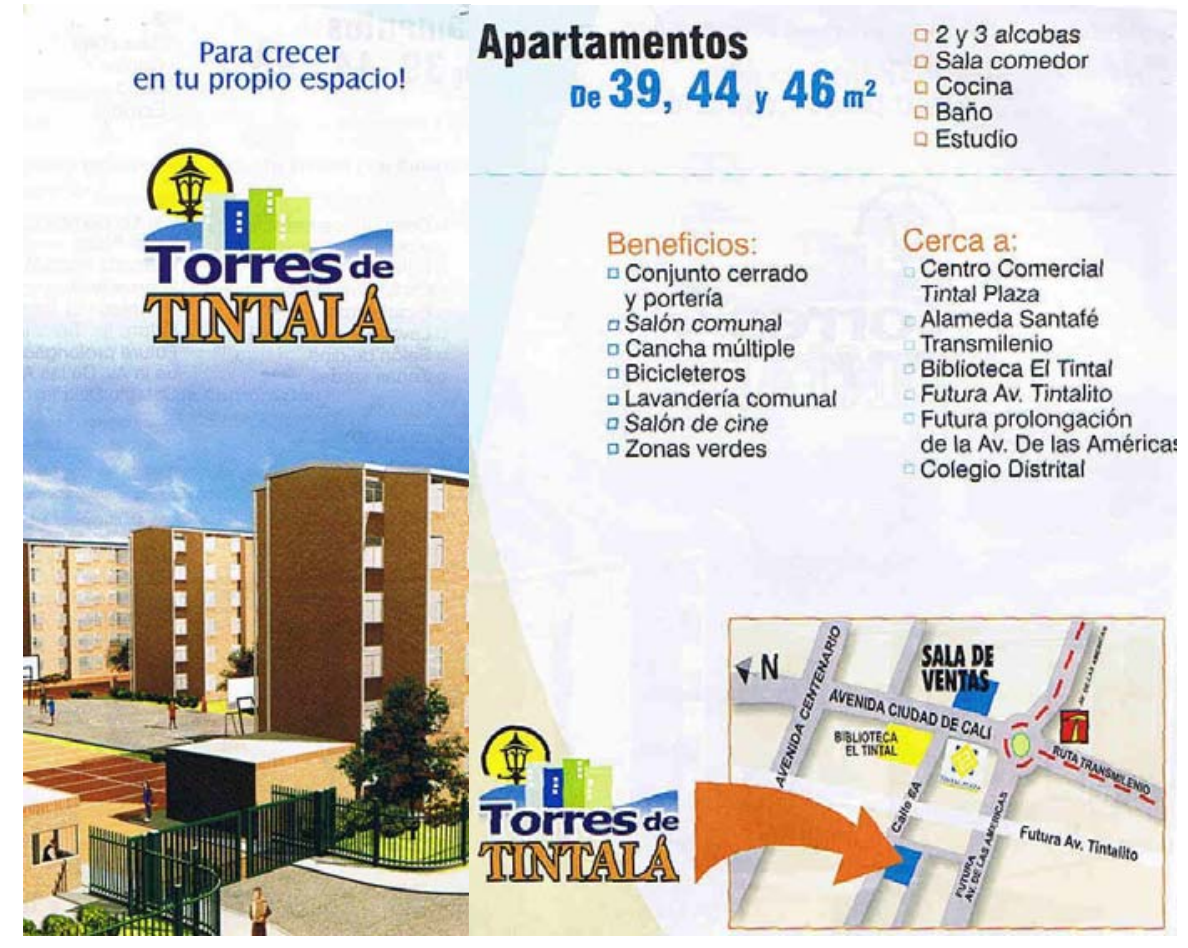

Fuente: Documentación de preventa de la Casa Muestra de Espacios Inmobiliarios. Bosa, oeste de Bogotá, 2006.

Este proceso, en efecto, acontece en España en los años 50, aunque se fragua paulatinamente desde la centuria anterior. Desde el punto de vista de una estudiosa de la inversión inmobiliaria con perspectiva histórica, y desde el campo de la experiencia de las ciudades españolas, es muy impactante la irrupción, del capital privado-inmobiliario en la construcción de estos megaproyectos de vivienda social latinoamericana. Simplificadamente, porque se trata de la comprobación de cómo con cincuenta años de retraso llega la producción masiva a ser objeto de interés para la inversión inmobiliaria profesional, y del mismo modo que ocurrió en España, por la intermediación del Estado que toma en este capítulo fundamental de su acción, una 
posición nítidamente mercantil, relegando su quehacer tanto social como de arbitro en la ordenación del territorio.

La escasez de agentes colectivos especializados caracterizó la promoción e inversión inmobiliaria en la segunda mitad del siglo XIX y muestra las carencias del sector inmobiliario ${ }^{23}$. Desde este punto de vista, de la indagación de la evolución de los sistema de inversión inmobiliaria, hoy, en las ciudades latinoamericanas, la actuación de un reducido grupo de sociedades inmobiliarias es ejemplar porque están ensayando nuevos productos e iniciativas de gran significación en la modernización de la inversión inmueble de sus sistemas inmobiliarios locales. Practicar la producción masiva les está permitiendo mayor profesionalización empresarial a las inmobiliarias, ingeniando nuevas formas y nuevos discursos que sostienen los cambios en el sistema de promoción inmobiliaria.

Los mecanismos, de producción masiva y cerrada, que utilizan en la producción de ciudad se reflejan en la forma de ésta y en los modos de organizar la propia vida urbana. Ya desde los primeros ensayos decimonónicos de producción masiva se demostró, al menos en por primera vez en España, que la producción de ciudad tiene "nombres propios". Son los nombres de los inversores responsables de la promoción del espacio urbano. En España los cambios en la forma de producir ciudad se van a reflejar en el plano de la ciudad entre 1870 y 1930 . Desde esas fechas la importancia superficial y numérica de los nuevos barrios periféricos determinan un cambio en el diseño y la organización de la propia representación de la ciudad que resuelve esta ruptura del continuo urbano provocada por estos espacios de reciente construcción incorporando hojas independientes. Es un recurso que desde entonces será frecuente para reflejar la tendencia a la colonización de espacios cada vez más periféricos, dispersos entre sí. Morfológicamente son espacios concebidos en conjunto, por ello, el nexo-calle deja de tener importancia tomándola la "agrupación", y es a ésta, a la que se le asigna una denominación propia. Los nuevos espacios se independizan del sistema ordinario del "callejero" y requieren una identificación exclusiva. La calle y la casa pierden importancia a favor del nuevo modelo constructivo y de organización espacial: el conjunto urbano.

Pero sin duda, el momento culminante de la producción masiva en España y el parejo desarrollo del sector inmobiliario como pilar económico del país, es como se apuntaba en la década de los cincuenta ${ }^{24}$ y sesenta del pasado siglo XX.

Ya desde la década de los 40 la actividad inmobiliaria observa importantes cambios de funcionamiento, tanto en los agentes involucrados como en sus formas de producir ciudad. Desde estas fechas cabe establecer una etapa en el desarrollo del sector inmobiliario caracterizada por presentar rasgos diferentes con respecto al modo tradicional de inversión que acaban por transformarlo, consolidándose un nuevo sistema de promoción. El sistema de promoción inmobiliaria queda definido principalmente por el progresivo dominio numérico de las

\footnotetext{
${ }^{23}$ Falta de modernidad del sector inmobiliario por la inexistencia de un entramado empresarial que dinamizase el sector inmobiliario y fijase las condiciones estructurales para el desenvolvimiento de la actividad promotora y por el "gigantismo" de algunos de los más grandes proyectos inmobiliarios emprendidos, respecto de sus bases de sustentación financiera y la existencia de una demanda raquítica con dificultades de compra para adquirir las costosas edificaciones resultantes, sobre un esquema de distribución extremadamente bipolarizado de los ingresos, además de insuficientes, no consolidados y con profundas oscilaciones. Un panorama con muchas similitudes al contexto latinoamericano actual.

${ }^{24}$ En esta etapa de la consagración de las nuevas formas de habitar, los nuevos paisajes del racionalismo y la consolidación de los principales grupos económicos y de poder, y su paralelismo con la vivienda social latinoamericana actual, hay que citar a la Inmobiliaria Urbis que ensayó fórmulas para popularizar el alojamiento con el Plan de Urgencia Social (Roch, 2003, 171) se aprendieron las cuestiones básicas para la producción masiva privada.
} 
inmobiliarias $^{25}$ que impregnan la inversión inmobiliaria de la modernidad necesaria. Fundamentalmente confiriendo al sector la estructura adecuada para su desenvolvimiento en la economía capitalista de la época. No obstante, la difícil coyuntura económica ralentiza la consolidación definitiva de las nuevas formas de promoción de suelo urbano y prolonga algunas manifestaciones de elementos arcaizantes. Esta etapa que comienza aproximadamente en 1940 se dilata hasta 1960.

A partir de los años sesenta cabe situar una nueva etapa, la de expansión del nuevo agente en toda su plenitud al amparo de las nuevas condiciones de la economía española. La larga etapa de fomento de la inversión inmobiliaria privada, ahora sin el freno de un mercado raquítico e intervenido, despega definitivamente apoyándose, primero, en las ventajosas disposiciones que siguieron caracterizando la política de la vivienda, y después, en una demanda potente y solvente económicamente. Las sociedades inmobiliarias aumentan progresivamente las cifras de ventas o robustecen su patrimonio en arrendamiento al tiempo que legislativamente se van puliendo notables irregularidades de su funcionamiento empresarial, en un intento de control legal e impositivo del sector ${ }^{26}$. En 1975 se confirma un rasgo que se apuntaba desde los años cuarenta a los setenta como era la concentración de capitales y la preponderancia económica de un grupo pequeño, es decir una estructura interna determinada por el contraste entre pequeña y dominante empresa y reducido grupo de grandes compañías con gran peso económico.

Han tenido un papel muy importante en la evolución urbana de Madrid del período comprendido entre los años 1955 y 1975 de gran trascendencia en la configuración actual de la ciudad. La expansión urbana de aquellos años triplicó la alcanzada a lo largo de su historia urbana y básicamente determinó la organización actual de sus barrios. La promoción residencial de estos años se caracteriza por el gran tamaño de las promociones, tanto en superficie como por el número de viviendas, y por el papel relevante de la iniciativa particular que casi siempre se organizó a través de sociedades inmobiliarias. La mayor parte de las viviendas construidas por la iniciativa privada formaba parte de homogéneos y grandes paquetes, de más de 10 hectáreas y 2.000 viviendas. Por consiguiente, ha sido de gran importancia el papel de la gran promoción residencial en los decenios expansionistas de la ciudad. Madrid creció, por la acción de unos pocos titulares de empresas, a base de grandes paquetes uniformes que definieron, y lo siguen haciendo hoy, amplios sectores de su periferia. En la actualidad estas grandes barriadas construidas en los años de formación de la periferia, siguen siendo piezas básicas de la ciudad por su magnitud; la política urbana desde finales de los ochenta las ha mejorado, convirtiendo amplias zonas de vivienda masiva en barrios residenciales al comunicarlos y equiparlos.

En definitiva, los promotores de grandes conjuntos urbanos fueron, sobre todo, pequeños agentes profesionalizados de ámbito local. Por todo ello, tienen un carácter en parte advenedizo y coyuntural, poco maduro, con elevada mortalidad y acusada fugacidad empresarial, aunque ésta incide diferencialmente según la estructura empresarial. Fueron en

\footnotetext{
${ }^{25}$ El seguimiento se ha realizado apoyándose en la información estadística que anualmente recoge el Anuario Sopec, S.A., antes Anuario RIU. Rodríguez, 1988, 393-401 y 1998.

262 Ley 19 septiembre 1942 (obligación de dotar reservas a cargo de beneficios), Ley 10 noviembre 1942 (obliga a la realización de balances consolidados ), Ley 31 diciembre de 1946 (de mayor control fiscal a las emisiones de capital) y Ley de Sociedades Anónimas de 17 julio de 1951 (exige el 25\% de capital desembolsado para la constitución de una nueva sociedad ) entre otras.
} 
gran parte empresas que ya habían ensayado la promoción masiva, la mayoría con resultados positivos, y de otras constituidas en los años sesenta, en ocasiones vinculadas a las anteriores, con el objetivo de atender los cambios de la demanda del mercado residencial. La mayor proporción la ocuparon empresas que habían sido creadas en los años sesenta, inversores coyunturales que se incorporaron en estos años al calor de un mercado muy dinámico y desaparecieron cuando llegaron las adversidades con la crisis económica.

Las promotoras del "Madrid masivo" son auténticas promotoras residenciales porque en su mayoría se crearon para dedicarse a la construcción de edificios residenciales al amparo de las modalidades de Renta Limitada. La mayoría tanto de las mayores promociones como de las promovidas por agentes emprendedores de varias promociones, se acogieron a los regímenes de financiación pública que la política de la vivienda arbitró desde los primeros momentos.

Por consiguiente, la periferia residencial y masiva se construyó por la aparición de unos agentes específicos, las inmobiliarias, que aprovecharon las ventajas de todo tipo que las políticas de la vivienda y otras medidas económicas crearon en aquellos años como engranajes de un modelo de organización territorial en grandes ciudades. Tres tipos de promotores inmobiliarios iniciaron grandes y uniformes barrios. Hubo empresas que resultaron de la agrupación de capitales familiares, se formaron sociedades por parte de profesionales diversos, sobre todo relacionados con técnicos y profesionales de la economía y la abogacía, y por último, se crearon inmobiliarias por otras empresas, como resultado de estrategias empresariales heterogéneas, casi siempre vinculadas al beneficio y al carácter intersectorial de este negocio. El negocio inmobiliario se amplió o se recondujo, según los casos, a través de la formación de nuevas empresas o, empresas de otros subsectores que reinvirtieron en operaciones residenciales.

La comparación española, con el caso de su capital, además de mostrar las bondades de los análisis sobre el agente ${ }^{27}$, sustenta la tesis de que se trata de un proceso equivalente de vivienda social producida por las grandes inmobiliarias y auspiciada por el Estado para captar el capital público de las instituciones de crédito. El conjunto favorece el desenvolvimiento moderno del sector inmobiliario latinoamericano y determina las formas de habitar ordenando en ese sentido el territorio.

En la ciudad latinoamericana actual, la totalidad de factores, procesos y productos favorecen la reactivación del sector inmobiliario y con él la naturalización del encierro urbano. En las ciudades de estudio el dato más singular del urbanismo cerrado de progresión mundial es, precisamente, este fuerte crecimiento del número de promociones populares y de viviendas en forma de vecindarios defensivos, así cómo también del tamaño de las operaciones económicas que implica y de la superficie consumida por el conjunto.

\footnotetext{
${ }^{27}$ Y sugerir la importancia y necesidad de abordar estos estudios en Latinoamérica para el esclarecimiento de muchos aspectos claves de sus ciudades.
} 
Figura $N^{\circ}$ 6: Interior y planta de vivienda social en oferta actual en la periferia occidental de Bogotá.
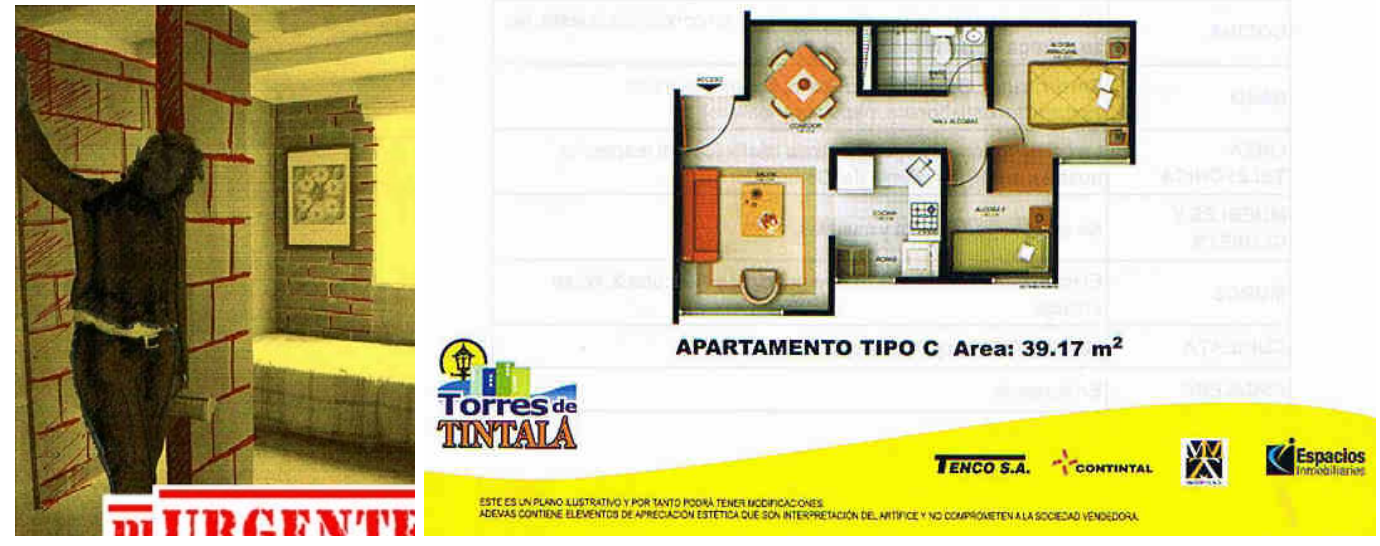

Fuente. Fotocomposición de la autora y documento de pre-venta de la casa-muestra de Torres de Tintalá (Bosa), Bogotá, 2006.

Estas grandes agrupaciones de microviviendas (Figura $N^{\circ} 6$ ) se desarrollan rediseñando tipologías arquitectónicas de vivienda mínima en producción masiva y unifamiliar, revitalizándolas dentro del nuevo formato del vecindario defensivo (Figura $N^{\circ} 7$ ), esto es, adicionándole a la morfología cerrada y la arquitectura hermética, una organización social que explícitamente busca el autogobierno en forma de comunidad para un grupo social ya rígidamente homogeneizado. El elemento de homogeneidad interna es la capacidad económica medida con el salomónico criterio de la capacidad de endeudamiento de los futuros compradores y avecindados. El espectro potencial de demandantes de crédito y vivienda ha sido abiertamente ampliado a un segmento más variado de la pirámide socio-laboral de trabajadores asalariados eventuales dentro de un mercado laboral fuertemente polarizado.

Por consiguiente, es el capital y la política financiera del país la que potencia y posibilita la progresión de las clonadas populares como nuevo modo de vida y de ciudad. Primero calles cerradas y después casas sin pasillo en calles cerradas para construir miniciudades con muros, utopías individualistas masiva e ingeniosamente producidas por el poder económico articulado en el viejo negocio inmobiliario creador de ciudad. Y así lo reconoce, obviamente soslayando el tema del encierro y el cerramiento en la perspectiva aquí manejada de su daño social y territorial, sino dentro de su naturalización que transciende a las viviendas y las tramas en análisis.

La proliferación de los megaconjuntos, que se concibe como una alternativa de cambio social y de nueva ciudad, se fundamenta en el ideario de privatizar espacios semipúblicos porque "son los que han permitido la subsistencia de estos espacios comunes (...) para lograr vivir en ellos y en armonía se requiere de una voluntad del grupo y de un buen diseño que propicie además una relación social duradera. De no ser así se convierten en espacios de conflicto y resultan peligrosos. De ahí la necesidad de someterlos a reglas más estrictas para el "buen vivir"' (Chávez, 2005, 382). Este es el ideario contenido en la reforma de la Ley de Propiedad en Condominio de Inmuebles para el Distrito Federal que regula la vida en condominios en la ciudad de México desde febrero de 2003 tras cinco años de producción febril de condominios, un ideario ensimismado exclusivamente en la visión singular, entre romántica y cínica, de entender que es el modo de vivir recuperando las áreas comunes, un espacio semipúblico a 
nivel de barrio: "con ello se promueve una nueva cultura urbana para que los espacios semipúblicos empiecen a ser solicitados por los mismos habitantes de los condominios (...) los grupos que demuestren carecer de recursos para atender por sí solos estos serviciosrecolección de basuras, luminarias, seguridad, protección civil, bacheo...-, para evitar que se sigan teniendo los niveles de deterioro a los que se había llegado en estos conjuntos, pueden pedir apoyo a la administración pública local y se organicen para ello" (383).

Figura $N^{\circ}$ 7: Vivienda social en el megaconjunto de Urbi en el norte del Estado de México.

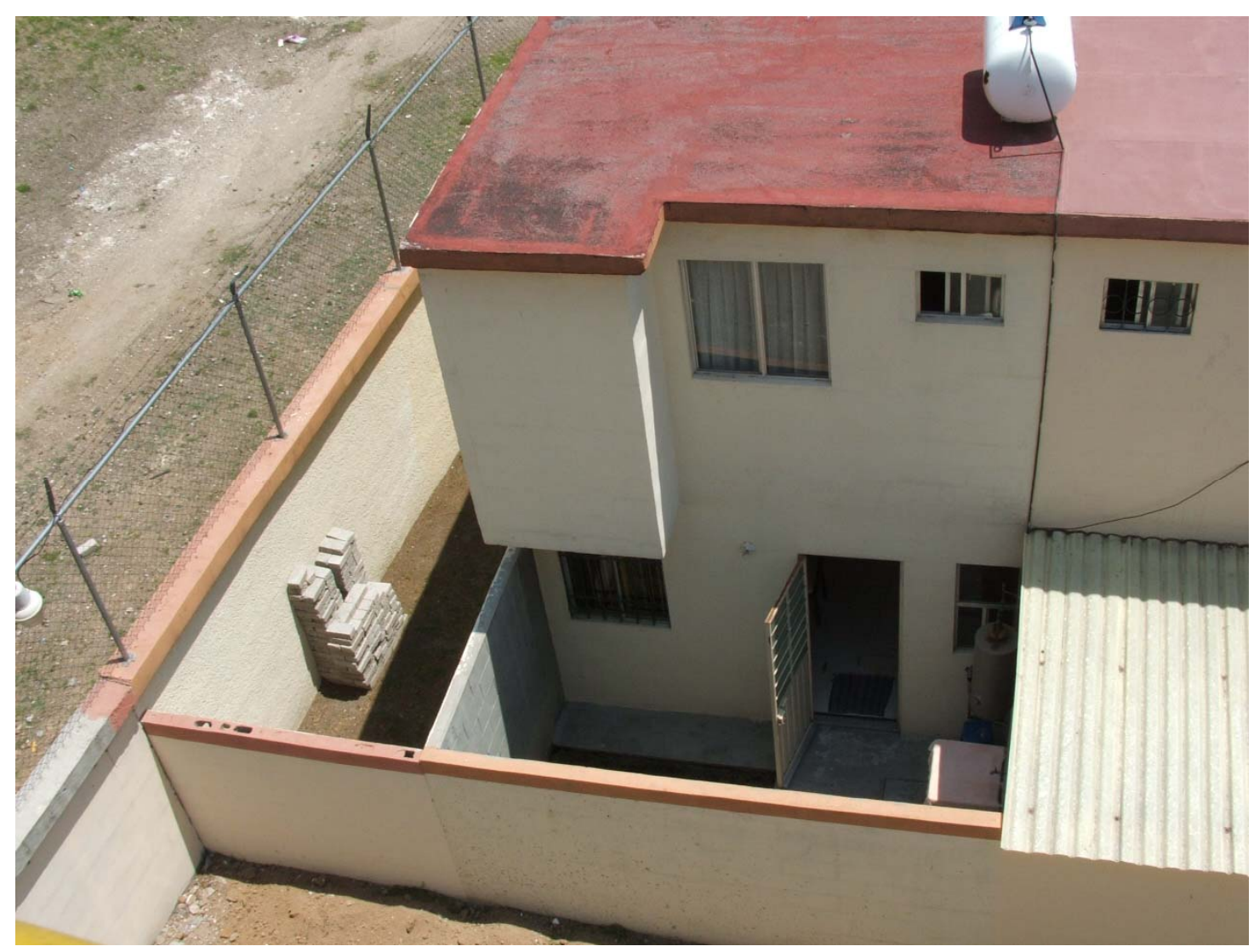

Fuente. Foto de la autora, México, 2006.

El urbanismo cerrado está en la esencia del programa de la vivienda social, al menos en México ${ }^{28}$ que ha sido mejor registrado ¿Son los contenedores herméticos dónde se encierran los "residuos humanos" que escruta y categoriza Zygmunt Barman en su obra "Vidas desperdiciadas"? ¿Es el modo que toma la ordenación de "seres humanos residuales" en la proximidad de grandes y crecientes aglomeraciones que probablemente lleguen a ser duraderas y que exigen políticas segregacionistas más estrictas y mediadas de seguridad

\footnotetext{
${ }^{28}$ En Colombia en el 2001 se reforma el marco legal vigente desde hacia cincuenta años, y así sintetizan los titulares de prensa la esencia de los cambios, en la misma línea del caso anterior: "Hoy la convivencia se fundamenta en la ley, el reglamento interno y el manual que la comunidad acuerda", facilitar el manejo de la copropiedad. El Código Distrital de Policía de Bogotá indica que la asistencia a las asambleas es deber ciudadno para fortalecer las relaciones de vecindad. Pabón, N Ley de Propiedad Horizontal: no hay quinto malo...El Tiempo, 5 de agosto de 2006.
} 
extraordinarias? ¿Se corresponde con la rigurosa separación de los "residuos humanos" del resto de la sociedad? (Bauman, 2005: 113). En parte si, pero sobre todo son "El País de las casitas" : "Miles de microviviendas surgen en México. A ellas van millones de pobres, excluidos durante décadas del rezago priista y ahora vistos como clientes pasivos por las constructoras" (La Revista, 2005: 26).

La abundante información ${ }^{29}$ sobre este tipo de fraccionamientos cabe pensar obedece a su carácter reciente, al éxito comercial que han despertado, lo que determina un riguroso control de la documentación en las dependencias municipales y a la campaña desplegada por el gobierno federal "para vanagloriarse de haber construido 1,5 millones de viviendas(...) entre 30 y 50 metros cuadrados (...) el doble de los construidos durante el sexenio anterior (...) Si, el gobierno foxista alcanzó una marca inédita" (La Revista, 2005, 27).

El Estado ha participado a través de los llamados Organismos Estatales de Viviendas (Orevis) en sólo $12 \%$ de las acciones, el resto es la iniciativa privada. Durante los últimos cuatro años se han construido casas mínimas con los 2 millones de créditos entregados por el Infoanvit, "la misma cifra que alcanzaron los regímenes priistas en 32 años" (27).

Producción masiva, en serie, idénticas, pequeñísimas, un país de cuartitos. Son sólo algunos de los adjetivos y características de esta producción profesionalizada de paquetes de vivienda homogénea que han ido ganando en tamaño, presentándose en conjuntos cada vez mayores y disminuyendo en el tamaño de la vivienda. El negocio de la construcción en México y también en el Norte fronterizo, vive un boom. "Hoy existen alrededor de tres mil empresas dedicadas a este ramo, de las cuales, unas 300 explotan el mercado de la vivienda social y 50 construyen casas económicas (...) estas últimas, que atienden al grupo de 2 o 3 salarios mínimos, destacan: Casas Geo y Urbi" (La Revista, 2005, 28).

Con las versiones de cerradas claramente populares, llamadas de interés social, se puede estar ante el segundo orden del simulacro definido por Baudrillard dentro de la producción del esquema dominante de la era industrial que él llama "El autómata y el robot" (Baudrillard, 1992, 62). El modelo de cerrada social es ese otro orden de simulacro que "está dominado por el principio técnico, es un logro de la máquina, y con la máquina es la equivalencia lo que se instala" (62-63). También, salvando las distancias cabe identificar esta producción masiva de alojamientos minúsculos con las urbanizaciones de protección oficial para familias de rentas bajas que Bauman cita refiriendo las semejanzas que Loïc Wacquant y Jerome G. Millar ven a su vez entre los guetos negros norteamericanos y el modelo carcelarios de las instituciones "goffmanianas": "una encarcelación del alojamiento público que cada vez hace pensar más en casas de arresto, con 'nuevos proyectos' 'cercados, con su perímetro férreamente vigilado por patrullas de seguridad y controles autoritarios" (Bauman, 2005, 109) ${ }^{30}$.

\footnotetext{
29 De tal modo que se disponen de cuatro de los convenios de autorización que informan de las principales características del primer importante conjunto en Nogales, Fraccionamiento San Carlos.

${ }^{30}$ Citando a Wacquant, 2002: 95-96 y Millar, 1997:101.
} 


\section{Las clonadas cerradas: ¿Reconquista inmobiliaria o nuevo ideario urbano?}

Una de las paradojas del territorio en tiempos de la globalización es que ésta desempeña el papel de coartada del quehacer público y al tiempo, sirve de oportunidad para el negocio privado. Respecto del quehacer público en todas las ciudades grandes de Latinoamérica, baste señalar que la configuración y dimensiones "derrochadoras" de sus territorios urbanos y el alto porcentaje de su espacio físico y social "precario", se entiende son expresivos y concluyentes de su política urbana deficiente. Además, el reforzamiento de los procesos de dualidad social, entre habitantes de asentamientos regulares (aunque también están aislados y desdotados) e irregulares, marginales por definición es una de las implicaciones más evidentes. Su reflejo en el territorio, por la escala e intensidad del crecimiento demográfico y espacial, evidencian un agravamiento de la segregación socio-espacial como principal efecto negativo de esta particular expansión territorial ${ }^{31}$.

Por consiguiente, todo conduce a una valoración negativa y crítica del quehacer público y sus mecanismos de control habitual mediante el planeamiento convencional. Sin embargo, desde mediados de los noventa funciona en muchas ciudades mexicanas los institutos municipales de planeación (IMPLAN e IMIP), nuevas instituciones públicas para atender los problemas de la ordenación urbana. El hecho de que ha transcurrido, en muchos casos, más de una década de su creación, y que ha coincidido con la fase de máxima expansión urbana, sugiere su corresponsabilidad en el tipo de crecimiento reciente. Se mantienen as grandes deficiencias, al tiempo que aumenta la mancha urbana, ampliando el espacio físico y social precario y la superficie urbana crece extensivamente, laxa, incluso en los proyectos programados sin resolver las necesidades de equipamientos e infraestructuras públicas.

\section{Figura $N^{\circ}$ 8: Vivienda clonada y encerrada}

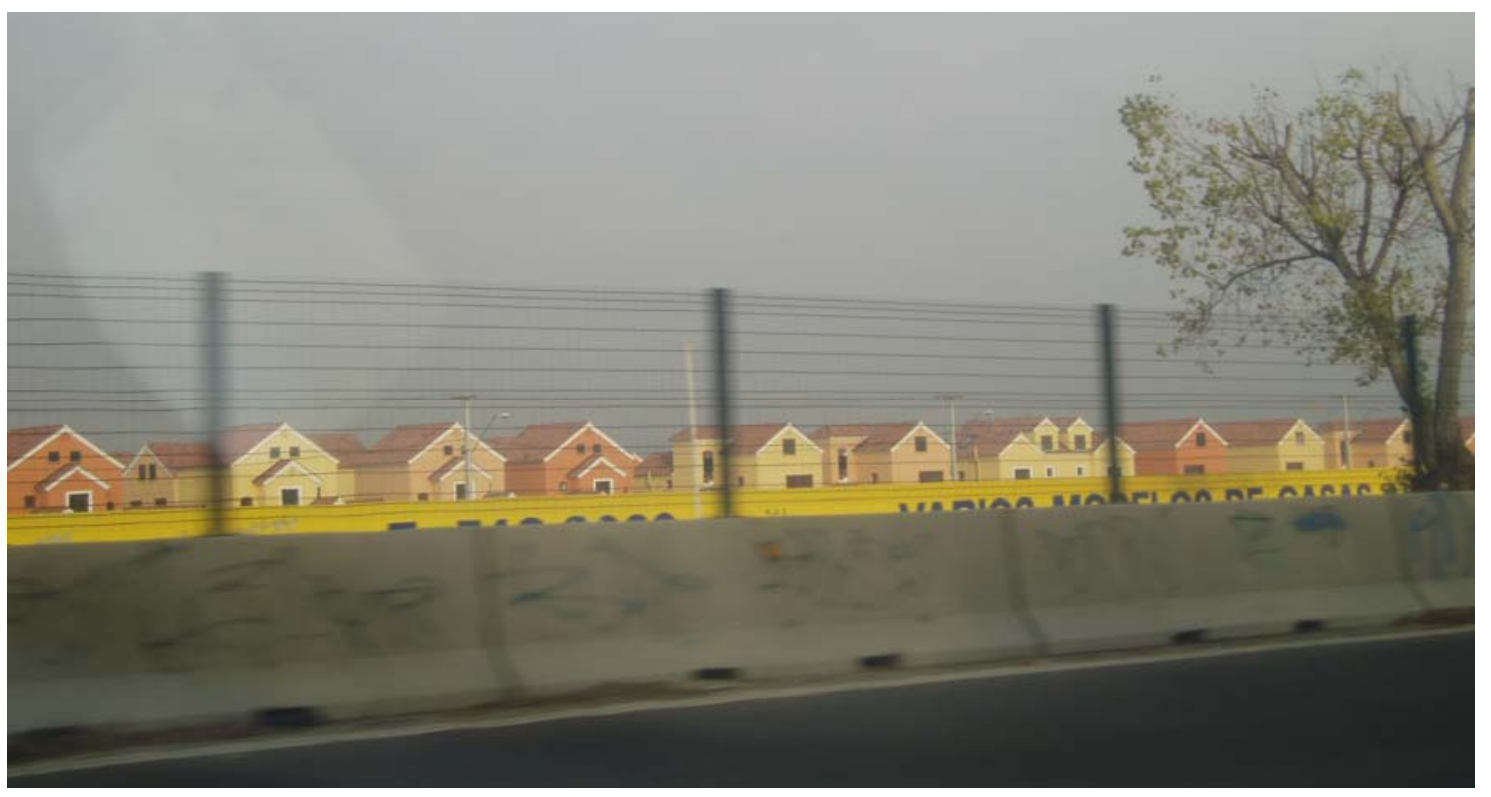

Fuente: Fotografía de la periferia de Santiago de Chile, 2005, de la autora.

\footnotetext{
${ }^{31}$ Lo anterior, teniendo en cuenta que, por lo pronto, no se consideran los severos desequilibrios medioambientales que produce a medio y largo plazo.
} 
Resulta paradójico, que en este contexto, las propuestas y ejecuciones de nuevos desarrollos campen en las inmensas periferias burlando todas las lógicas de la producción sostenible, en medio de la nada, sin conexión con la ciudad, ni siquiera con la red básica de infraestructuras urbanas, a caso, teniendo cómo vecindad una maquila o una derivación del nuevo viario. Así, sin ninguna otra lógica que la del mercado del suelo y el manejo tosco de su revalorización y puesta en valor de los terrenos, han aparecido grandes agrupaciones de casas aisladas en el territorio y de la ciudad como pretenciosas miniciudades, por su tamaño y por el desapego con la otra ciudad, alejándose de una autosuficiencia que en absoluto tienen (Figura № 8).

Estas configuraciones aberrantes ${ }^{32}$ indican una gestión pública deficiente en la medida que ha posibilitado la "invasión" del territorio en todos sus rumbos y con ella ha favorecido la reconquista territorial por parte del capital inmobiliario en alianza con los grupos de poder local (muchos grandes terratenientes). Esta reconquista del territorio hacia los canales de control del mercado, y de los que controlan a su vez el mercado, propietarios e inversores, comenzó en los años noventa a partir de la modalidad de conjuntos cerrados. Ha supuesto impresionantes movimientos de tierra ${ }^{33}$ y un jeureka! en los negocios inmobiliarios ${ }^{34}$ que se orientaron a la producción masiva de vivienda de clase media baja a gran escala.

Las extraordinarias oportunidades de negocio que han representado las atestigua la llegada de las principales inmobiliarias del país ${ }^{35}$ (Figura $N^{0}$ 9). Son las protagonistas de esta reconquista que provoca la aparición de grandes paquetes de vivienda de clase medía-baja, en la idea de que muchos habitantes pueden vivir mejor aunque sea atados por una hipoteca gracias a la intervención consensuada de los sistemas financiero y político.

\footnotetext{
${ }^{32}$ Las áreas de intervención así cómo la misma propuesta urbanística, incluso en términos de diseño arquitectónico, son un error para con el medio, para la propia práctica de la planeación y la gestión urbana así como para el progreso de la propia cultura. Cómo dice Norberto Cháves: "Proyectar un lugar habitable, o sea, un espacio con sentido, es transcribir las expectativas de su habitante -individual o colectivo, real o potencial- en los términos de un código socialmente válido" (55), y las macrointervenciones cerradas para producir microviviendas clónicas son una intervención que altera profundamente el medio sin contrapartida ni ganancias que compensen en el medio social.

${ }^{33}$ Estas intervenciones masivas sobre el territorio suponen una potente transformación del espacio, frecuentemente con allanamientos del terreno que explicitan la capacidad del hombre con sus máquinas cuándo la maquina inmobiliaria decide mover las piezas del juego, y ganar la partida del tablero inmobiliario, entonces, los cerros desaparecen las vaguadas se rellenan y una tupida red de infraestructura tapiza de técnica y confort el territorio. El artificio humano construye ciudad.

${ }^{34}$ Estas potentes inversiones son posibles en parte por la llegada masiva del capital foráneo que ha repercutido también en el mercado del suelo, no sólo a través de la demanda directa de grandes extensiones para los nuevos usos comerciales e industriales sino, sobre todo, mediante la reconversión hacia el sector inmobiliario de importantes capitales locales antes dedicados a la producción manufacturera o al comercio.

${ }^{35}$ Obviamente ello representa que también otros grupos empresariales locales se han beneficiado directamente de alguna de las fases lucrativas del proceso de promoción inmobiliaria. Por ejemplo, en Chihuahua. Los grandes empresarios que heredan fortunas de dos o tres generaciones, han reconvertido y multiplicado sus actividades, en parte porque se pudieron beneficiar de concesiones municipales y porque compraron a los ejidatarios extensos terrenos periurbanos baratos en los años sesenta. Fueron promocionados para parques industriales y hoy siguen suministrando nuevo suelo para maquilas y fraccionamientos populares cerrados. Ejemplo elocuente es el caso de Jaime Bermúdez que según recoge la autora citando a Alejandra Salas (1992), cuándo fue alcalde de Ciudad Juárez promovió siete parques industriales. (Rivière d'Arc, 2000, 57).
} 
Figura $N^{\circ}$ 9: Condominios de Urbi en el norte de la ciudad de México, 2006.

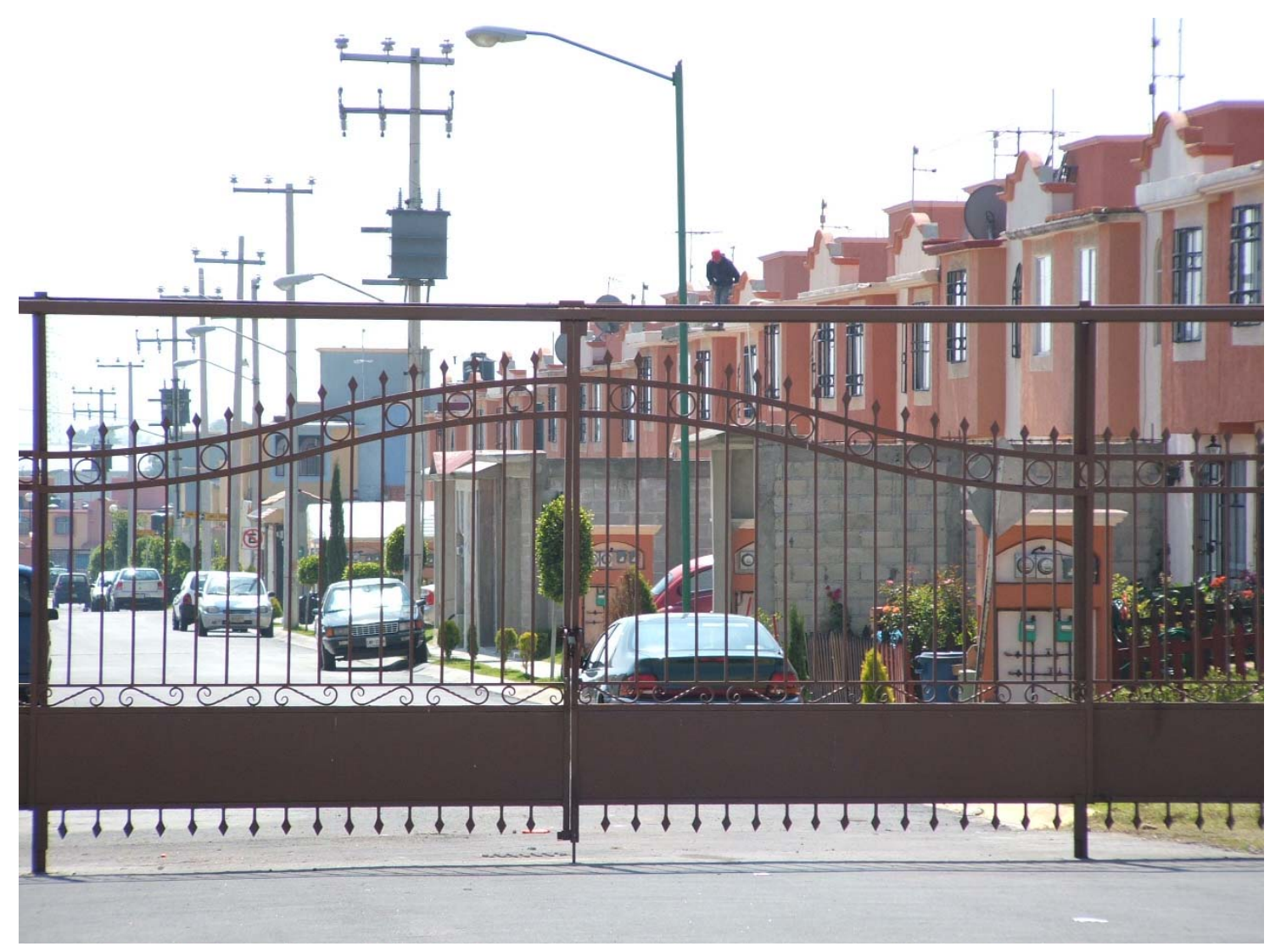

Fuente: Fotografías de la autora.

La política empresarial ${ }^{36}$ es pues, sin las cortapisas del control público, la protagonista de las nuevas tendencias urbanas, los "hacedores",37 de la ciudad ${ }^{38}$. Estos cambios en los promotores y sus modos se están reflejando nítidamente en el territorio. Hasta el extremo de que son sus decisiones empresariales las que determinan la construcción de la ciudad latinoamericana.

En el caso del Nuevo Tijuana y la Nueva Juárez, es del negocio del que ha dependido que sean los sectores del gran sur-oriente y oriente (Figura $N^{\circ} 10$ ), los que constituyan tanto el gran tamaño de lo conjuntos residenciales (a base de megaoperaciones por sucesivas fases de varios miles de viviendas), cómo el consecuente referente de vida de muchas jóvenes familias. Sobre todo, por la implicaciones múltiples de su diseño del nuevo modo de vida urbana aislado del resto y cerrado en la casa ideal que es la casa segura. En estas ciudades norteñas se han levantado en los últimos cinco años grandes complejos masivos para las

\footnotetext{
${ }^{36}$ Las ciudades de la región fronteriza norteña viven igual que el resto de México un proceso de profesionalización y concentración del sector inmobiliario desde finales de los ochenta que hasta los noventa no se ha manifestado con contundencia, cuándo el soporte necesario de políticas colaterales cómo la de la vivienda y los compromisos financieros se han consolidado.

${ }^{37}$ Papel de dominio del promotor en la producción de ciudad. Su mano maneja los destinos y construye la ciudad.

${ }^{38}$ También son "hacedores" de ciudad, los otros hacedores, los autoconstructores de su alojamiento, habitantes de la frontera, y por cierto los más numerosos, aquellos autodidactas que provisoria y sutilmente levantan millones de casas precarias en los cerros y cañadas.
} 
clonadas y minúsculas casas-nicho ${ }^{39}$. Estas viviendas son los nuevos productos de éxito de todos los hacedores profesionales, locales (más modestos en la clonación) y externos (los principales del país). Diversos factores, en efecto, favorecen su conversión en producto estrella.

Figura $N^{\circ}$ 10: Clonadas de interés social en la Mesa de Otay, Tijuana, Baja California, 2005.
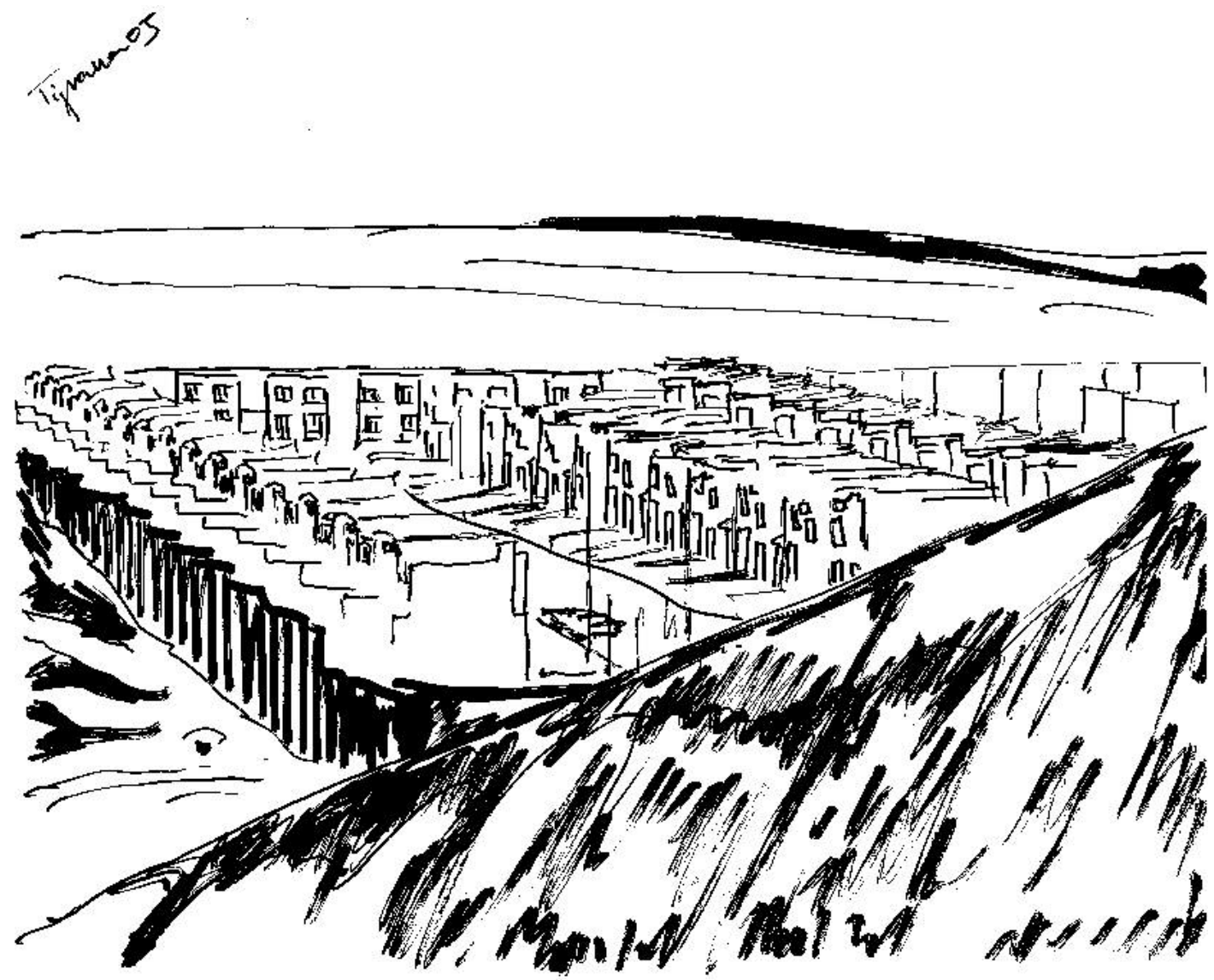

Fuente: Dibujo de la autora.

En México, el estilo lo marca "Vida residencial", la vida "Urbi", el crédito publicitario de la empresa norteña Urbi, hoy una gran inmobiliaria de ámbito nacional con gran éxito en la Bolsa de valores del país ${ }^{40}$. Urbi Desarrollos Urbanos, con su eslogan "Vida residencial", ilustra cómo

\footnotetext{
${ }^{39}$ Casas de pequeñas dimensiones promocionadas masivamente con créditos oficiales. Son las mismas casas sin pasillo en calles cerradas de un espacio físico clonado y anónimo, producto estrella del sector inmobiliario mexicano actual y al que el habitante fronterizo también debe hacer habitable, cómo si se tratara de un lote vacío del que lograr un espacio social construido. El necesario milagro para dotar de habitabilidad a este anónimo, escaso y deficitario espacio urbano pasa por los aberrantes reglamentos de las promotoras que abogan por un control del conjunto.

${ }^{40}$ Creada en 1981 por Cuauthémoc Pérez Román, arquitecto, y hoy presidente del grupo con delegaciones en varios estados del país después de haber centrado su actividad en Chihuahua ente 1995-2006.
} 
se maneja el negocio. Vida residencial es al mismo tiempo el producto en el que se especializa dentro del mercado inmobiliario, la idea central de su objetivo empresarial ${ }^{41}$ y su propia estrategia cómo empresa. Se definen convencidos y seguros creadores de un concepto de ciudad, capaces de hacer realidad mucho más que una casa, tanto cómo un modo de vida definido por una cultura comunitaria con capacidad de reconquistar el territorio a la deriva y colonizarlo con un nuevo grupo social ${ }^{42}$. La filosofía humanista para los empleados promueve lo que llaman "el espíritu grande". Consiste en creer para crear por "el prestigio del hacer"33. Creen también que es la base de "una sólida y original cultura corporativa" que también ha desarrollado un vocabulario propio ${ }^{44}$. La casa Urbi es la más abundante porque su actividad en estas ciudades es muy destacada, habiendo prácticamente monopolizado la "detonación" de los nuevos sectores periféricos .

Figura № 11: Cerradas sociales en Tijuana, Baja California, 2005.

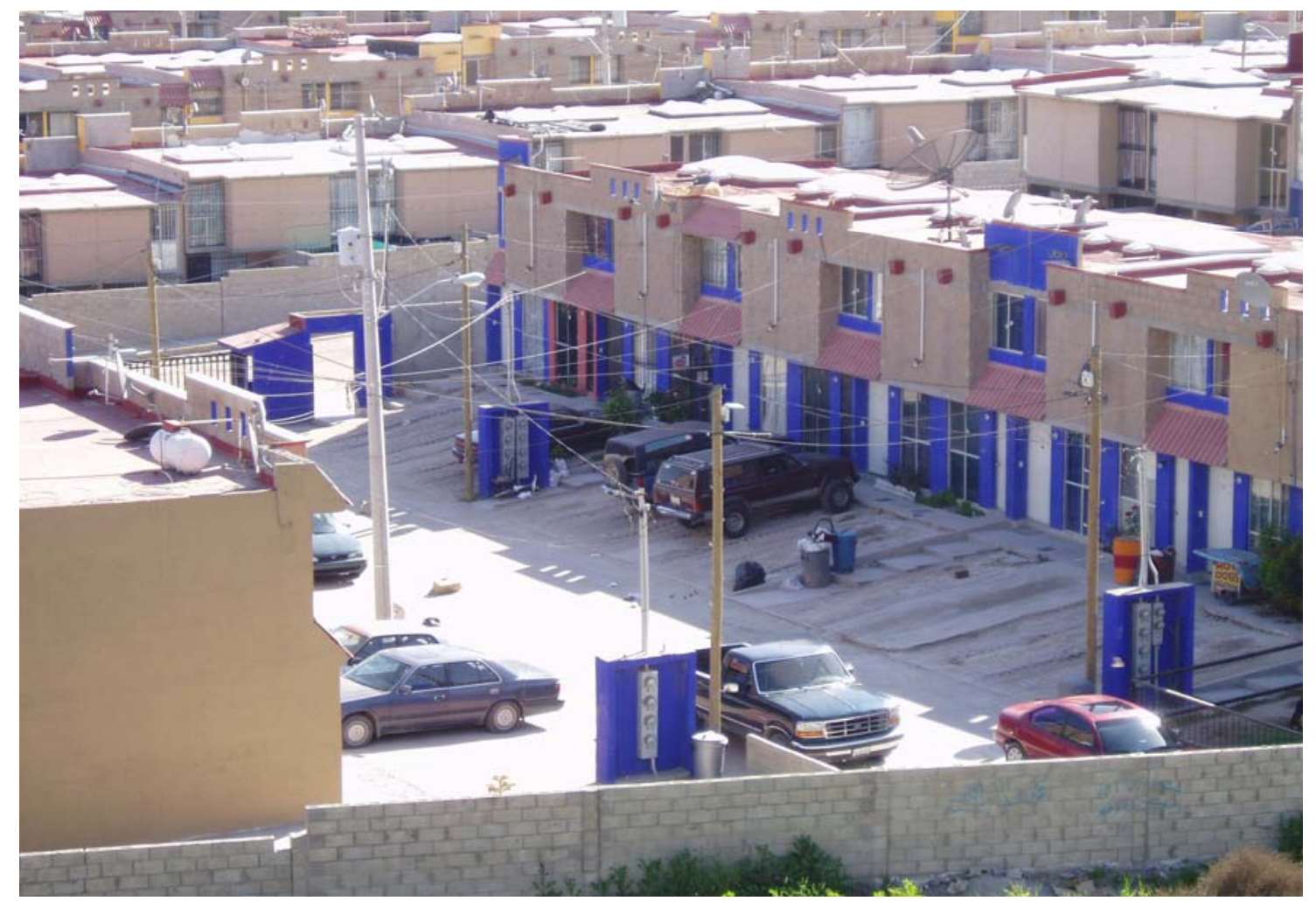

Fuente: Fotografía de la autora.

\footnotetext{
${ }^{41}$ El Plan Maestro Comunitario reúne el sistema completo de razonamientos que desarrolla la idea de Vida Residencial de Urbi.

${ }_{42}^{2}$ La empresa explicita su objetivo de "reconstruir la clase media del país". El Kilo, órgano de difusión interior de Urbi Desarrollos Urbanos, 2005.

${ }^{43}$ El Kilo, órgano de difusión interior de Urbi Desarrollos Urbanos, 2005.

44 Dice la empresa Urbi que "describe actitudes y situaciones del negocio". Difunden este diccionario de su propio idioma en El Kilo, en su tercer año de edición cómo órgano informativo interno trimestral. El kilo, año 3, n ${ }^{\circ}$, eneroabril. 2000 ejemplares. Vocabulario Urbi en la contraportada.
} 
El esquema se repite, en la vivienda promovida por otras inmobiliarias ${ }^{45}$ (Figura $N^{0} 11$ ) y en otras ciudades de la frontera noroeste ${ }^{46}$. Consiste en viviendas ${ }^{47}$ de $30.70 \mathrm{~m}^{2}$ (en parcelas de $41.20 \mathrm{~m}^{2}$ ) agrupadas en conjuntos de viviendas variables. En Ciudad Juárez y Tijuana los sueños en serie clonan sus periferias materializando un espacio físico que expresa mayor distanciamiento social, dónde la exacerbación de valores individualistas y la pérdida de referentes identitarios, todos, contradictorios con los tópicos más ansiados de las utopías urbanas, demuestran las consecuencias negativas de una idea de ciudad basada en la exclusión.

Diversos factores, favorecen su conversión en producto estrella (Figura № 12) además de los estructurales arriba apuntados. Según Elvira Maycotte (2005) en el caso de Ciudad Juárez ${ }^{48}$ son las que más y mejor se venden son las que ya categorizadas cómo "clonadas populares"49 que se han multiplicado por diez y los 69 construidos han producido 3.567 viviendas suministrando alojamiento a casi 15.000 nuevos residentes en cerradas populares ${ }^{50}$.

Figura $N^{\circ}$ 12. Publicidad de la inmobiliaria Urbi de mayo de 2006 manejando el producto vivienda cómo una mercancía de consumo más para su difusión

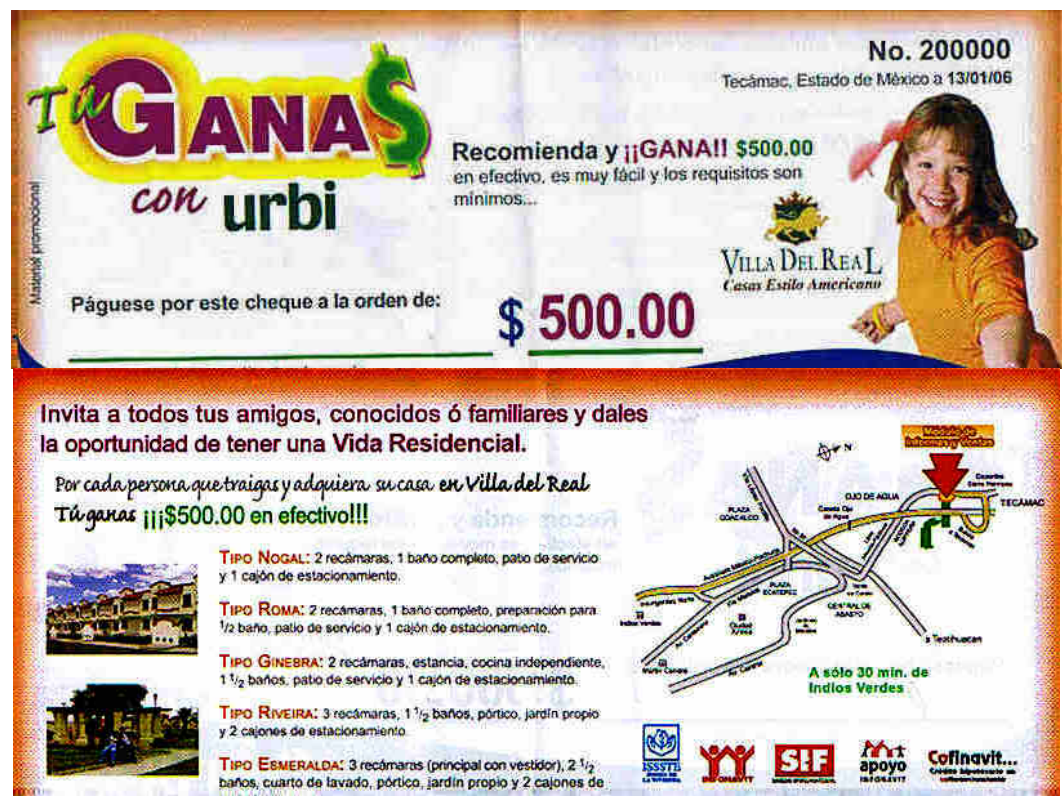

Fuente: Urbi, Desarrollos Urbanos. Publicidad en la zona norte metropolitana de México, 2006).

\footnotetext{
${ }^{45}$ El caso de Brasa revisado por Sergio Castillo (2005) para Ciudad Juárez. Aporta datos y valoraciones no sólo del producto de las cerradas de clase media e interés social sino que además, manifiesta una explícita preocupación por caracterizarlo. Se trata también de una empresa de ámbito regional que actúa en los estados fronterizos de Baja California Norte, Sonora, Chihuahua y Tamaulipas que ya ha desplegado una gran infraestructura para el desarrollo de sus comunidades. Según este autor su estrategia empresarial está influida por las promotoras norteamericanas "que han tenido la visión mercantil de proporcionar una vivienda (producto), dentro de un ambiente muy valorado por la clase media y alta" (Ibídem), sin embargo, en el mismo ámbito de la región fronteriza se han comprobado cómo promotores locales y con una producción también local, cómo en caso de Nogales (Sonora) el esquema es el mismo y todo apunta a las propuestas profesionales sin vínculo con la citada producción estadounidense (Rodríguez, 2005).

${ }^{46}$ Esquema que también se cumple en otras ciudades de la frontera noroeste de México.

47 Dormitorio, un baño y una habitación de usos múltiples.

${ }^{48} \mathrm{La}$ autora compara los fraccionamientos y condominios aprobados durante el primer semestre de los años 2001 y 2003 que obran en la Dirección de Desarrollo Urbano de Ciudad Juárez, Chihuahua.

${ }^{49}$ Méndez-Rodríguez, 2004 y Rodríguez, 2005.

${ }^{50}$ Con una media, según el II Censo de Población y Vivienda de 2000 de 4.15 personas por vivienda (Maycott, 2005).
} 
Son, en efecto, la oferta residencial de la población obrera pues el $81 \%$ de los trabajadores son empleados -obreros o peones - y el 56\% gana de 1 a 3 salarios mínimos ${ }^{51}$ (Ibídem, 2005, 1012). Los condominios son la figura que permite a los promotores aprovechar intensivamente el suelo combinando una parcelación muy acusada (Figura $N^{\circ} 13$ ), un tratamiento de las zonas verdes especulativo y demagógico y otras infracciones flagrantes. Destaca el tema de las donaciones de suelo en las estipuladas por la normativa del Estado "áreas de donación" que las resuelve con superficies residuales y dispersas, frecuentemente, ubicadas en sectores abruptos, o impropios a la urbanización desde el punto de vista topográfico y, por tanto, de muy difícil utilización para usos del suelo urbanos.

Figura $N^{\circ}$ 13: Grandes conjuntos en la periferia oriental.

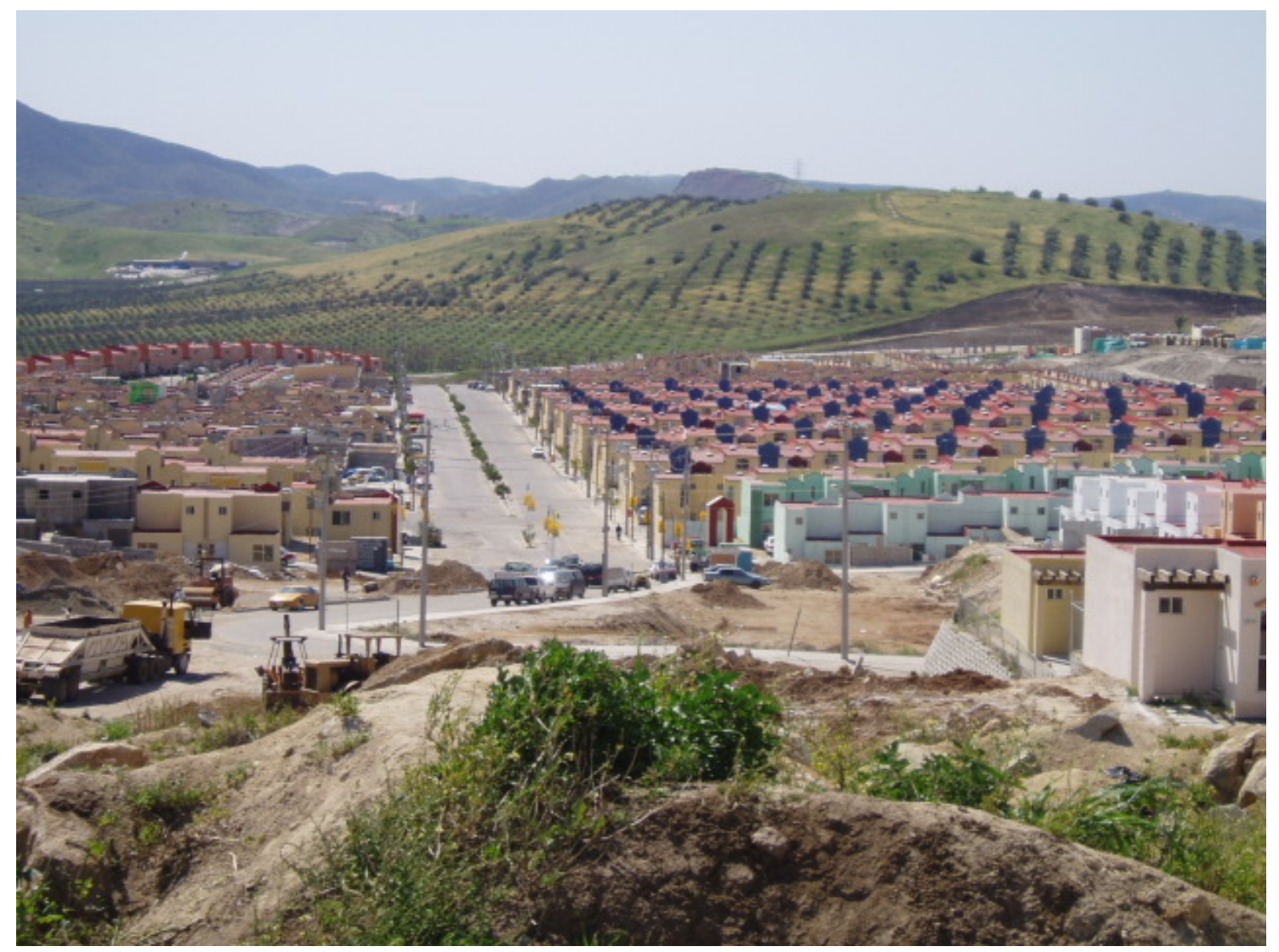

Fuente: Tijuana, Baja California, 2005. Fotografías de la autora.

Se han distinguido cuatro factores esenciales para explicar la proliferación de vivienda económica en Ciudad Juárez: "programas gubernamentales de financiamiento para vivienda social; perfil socioeconómico de la población, normatividad aplicable y por último, el neoliberalismo económico y el mercado de vivienda" (Maycott, 2005, 8). Confirma la autora las condiciones actuales de los créditos y el rápido proceso de deterioro de las viviendas (2005, 13) que también se cumple en Tijuana en el muestrario de imágenes que se ofrece en el presente trabajo. Es decir, en el contexto económico global, la base social pauperizada de las ciudades fronterizas es absorbida por la vorágine de una producción de vivienda social dentro

\footnotetext{
${ }^{51}$ Según la autora citada la mayoría están dentro del rango más bajo de 1 y 2 salarios mínimos.
} 
de los circuitos del interés del sector inmobiliario profesional. $Y$ concretamente, de un sector inmobiliario fuertemente marcado por el monopolio, pues el $72 \%$ de las viviendas fueron construidas por sólo tres promotores: Condak, Ruba y Urbi ${ }^{52}$.

La casa Urbi es la más abundante entre las casi 4000 promovidas en Ciudad Juárez en 2003, y su actividad en Tijuana también es muy destacada, habiendo prácticamente monopolizado la implosión de las tierras en la periferia suroriental entre la Carretera de Ensenada y el municipio costero de Rosarito. El esquema se repite, en la vivienda promovida por otras inmobiliarias de Ciudad Juárez y Tijuana. Consiste en viviendas ${ }^{53}$ de $30.70 \mathrm{~m}^{2}$ en parcelas de $41.20 \mathrm{~m}^{2}$ agrupadas en conjuntos de 16 a 95 unidades a base de módulos de cuatro viviendas en lotes de $200 \mathrm{~m}^{2}$ de superficie (15).

En las interpretaciones que hasta la fecha ha recibido este fenómeno por parte de los estudiosos locales se pone el énfasis en las incongruencias del propio producto analizado en sí mismo, cómo la contradicción que se reconoce entre la densificación residencial privada por la que se aboga en los condominios y los necesarios paliativos que debe ofrecer el espacio público complementario. No se han considerado otros efectos cómo los de su articulación con el resto de la ciudad ${ }^{54}$ (Figura $N^{0} 14$ ): "Es contradictorio que la normatividad promueva la densificación y no ejerza la planeación y administración urbana oportuna precisamente en aquellos sectores donde el espacio público y equipamientos son más necesarios. Si hemos reconocido que la normatividad da lugar a tipologías y morfologías distintas, entonces debemos reflexionar sobre el impacto que tiene en las soluciones que actualmente se observan y los espacios que produce" (21 y 22).

Figura № 14: Recientes desarrollos de Urbi en el estado de México: Tecámac, México, 2006.

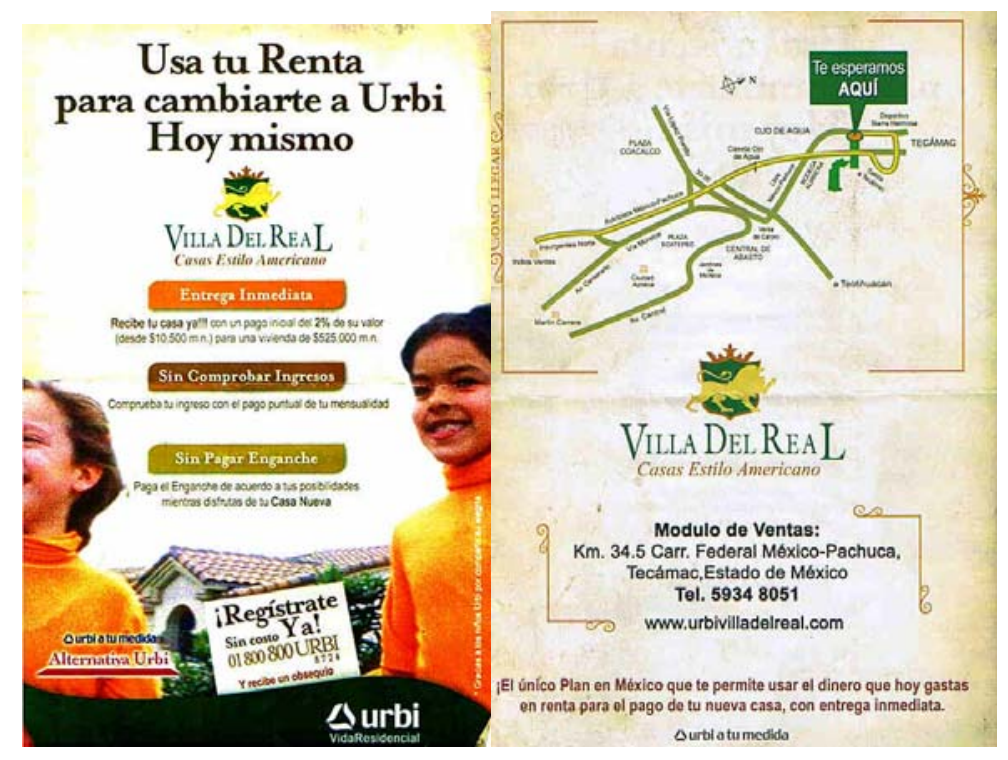

Fuente: Urbi desarrollo Urbanos

\footnotetext{
${ }^{52}$ Urbi promueve 14 conjuntos (el 36\% de todos los conjuntos habitaciones), Ruba, 11 (el $28 \%$ ) y Condal 6 (Maycott, 2005, 14 y 15).

${ }^{53}$ Dormitorio, un baño y una habitación de usos múltiples.

${ }^{54}$ Méndez, López y Rodríguez (2006).
} 
En general, cuestiona ${ }^{55}$ las que llama "restringidas perspectivas de calidad de vida" (20), concluyendo que "el estilo de vida que propone el modelo de condominio "puede ser una alternativa para quienes lo adoptan voluntariamente y así se integran a un grupo más o menos homogéneo, sin embargo, no lo es para aquellos a quienes se les impone, cualquiera que sea la razón". No obstante, observa entre los factores para la integración comunitaria ${ }^{56}$ que contempla la promotora bajo e lema: "'enseñarles a vivir en comunidad" que "no es una estrategia sostenible por varias razones porque "no existe una garantía de que los promotores tengan la suficiente capacidad para afrontar un problema social de tal magnitud" y porque se requiere una capacitación permanente no garantizada por un promotor privado" (Maycott, 2005, 20 y 21).

Es infrecuente la preocupación por el agente promotor en la producción de ciudad, también en la nueva: El caso de Brasa revisado por Sergio Castillo (2005), a diferencia de lo anterior, aporta datos y valoraciones no sólo del producto de las cerradas de clase media e interés social sino que además, manifiesta una explícita preocupación por caracterizarlo. Se trata de una empresa de ámbito regional que actúa en los estados fronterizos de Baja California Norte, Sonora, Chihuahua y Tamaulipas que ya ha desplegado una gran infraestructura para el desarrollo de sus comunidades (Figura $N^{0} 15$ ). Según este autor ${ }^{57}$ su estrategia empresarial está influida por las promotoras norteamericanas "que han tenido la visión mercantil de proporcionar una vivienda (producto), dentro de un ambiente muy valorado por la clase media y alta", sin embargo, en el mismo ámbito de la región fronteriza se han comprobado cómo promotores locales y con una producción también local, cómo en caso de Nogales (Sonora) el esquema es el mismo y todo apunta a las propuestas profesionales sin vínculo con la citada producción estadounidense (Rodríguez, 2005).

En este sentido, aplica en sus promociones el esquema de los reglamentos de construcción internos que anexa al Reglamento de Construcción del Municipio de Ciudad Juárez y también la figura jurídica del fideicomiso que brinda la seguridad de la conservación a los residentes tanto del mantenimiento de las áreas comunes cómo de la accesibilidad, obviamente, sin pertenecerles legalmente la propiedad y gestión de esos suelos y servicios. Es, una de las fórmulas más exitosas aplicada por buena parte de los promotores, independientemente de su tamaño empresarial y de su importancia local en la producción residencial. No obstante, el Reglamento interno hace referencia a numerosos aspectos complementarios y vitales en la definición del nuevo producto (Méndez-Alvarado, 2004), siempre restricciones tanto para la edificación, en un intento por uniformizar la apariencia de las viviendas con tratamientos normalizados para las fachadas a fin de homogenizarlas ${ }^{58}$.

Comunidades Brasa maneja varias líneas de productos dentro de la misma gama de fraccionamientos cerrados para clase media, diferenciándose y especializándose dentro de

\footnotetext{
${ }^{55}$ Cuestiona el grupo social destinatario de las ayudas financieras del programa de vivienda social oficial (tienen posibilidades de acceder a otras fuentes de financiamiento y por el alto porcentaje de renta se evidencia el uso cómo valor de cambio de la vivienda social) y al propio programa que califica de "el más importante y ambicioso programa oficial con alcance nacional" (Ibídem).

${ }^{56}$ Las encuestas realizadas a los residentes del Condominio de Parajes del Sol confirman las prácticas sociales de distanciamiento entre los vecinos, de desconocimiento de los Reglamentos internos que determinan estos derechos deberes comunitarias, así como sus opiniones respecto a la las funciones públicas sobre las áreas verdes. ${ }^{57}$ Castillo, S. (2005), consultando la web de la empresa: http://www.brasa.com.mx/galeria.ssp, (12 de junio de 2005).

${ }^{58}$ En el caso concreto a través de reglas denominadas "Diseño y ambientación: el fraccionamiento deberá de ser del tipo Colonial Mexicano, California, Americano o similar que sea aprobado por el promotor, por lo que todas las edificaciones deberán llevar esa ambientación del estilo arquitectónico."
} 
este segmento con distintos aditamentos y recursos para atraer las variantes a la alta y a la baja, absorbiendo el espectro de clase media en desarrollo en las dinámicas ciudades fronterizas cómo Ciudad Juárez ${ }^{59}$ (Figura No 16). En la promoción Comunidad Residencial la Rioja, la línea de productos estilo español es "una propuesta mercantil por ofrecer un estilo inexistente y con la finalidad de realizar una seudo comunidad temática con referencias a la península ibérica" (Ibídem).

Entre las críticas más explícitas destaca la evidencia de una actuación incoherente respecto a la calidad del entorno, pues según el autor, sólo hay una preocupación por la apariencia 'interior de la comunidad': "solo les importa la "ambientación" de las fachadas frontales" y cita el caso de la regulación de los tanques y aires acondicionados que "deberán ocultarse a la vista desde el frente de la casa." Lo mismo se puede corroborar este proceder en el uso del término "calle" a las circulaciones interiores de la comunidad solamente, exponente de un elemento de gran visibilidad y vínculo con el resto de la ciudad. Se trata del paisaje urbano que definen estos agrupamientos de vivienda. Este trabajo repara en el perfil urbano que ofrece al resto de la ciudad la comunidad cerrada organizada hacia el interior y en la que por tanto, en el exterior, además de la barda ${ }^{60}$, el elemento urbano lo define la confluencia de un gran número de fachadas traseras de las viviendas: "con plena vista desde el exterior de la comunidad puede observarse la misma diversidad desordenada que se observa en la ciudad, surge entonces la duda de para que sirve un reglamento que solo se preocupa de regular la escenografía interior, pues la imagen urbana que de estos fraccionamientos se tiene esta muy influenciada por sus apariencia externa, dejando en entredicho sus mensajes publicitarios como "La Rioja, es una Comunidad planeada integrada por varios Residenciales que embellece la ciudad "' (Ibídem).

Entre los cerros de Nogales, cuya mayor parte son espacios que aún están muy lejos de presentar niveles de consolidación importantes dónde la pátina del hombre ha creado rincones humanos y bellos, útiles para la vida y el alma de sus gentes, se han instalado grandes paquetes aislados de vivienda.

\footnotetext{
${ }^{59}$ Esto es aplicable para aquellos que deseen acudir a un profesionista para realizar la vivienda acorde a sus necesidades, la empresa también ofrece otros modelos con distintos requerimientos estilísticos "sacados de un ambiente imaginario y artificial".

60 "El límite físico formado por estas comunidades es formado por la acumulación de divisiones parcelarias que forma el conjunto de viviendas, estas bardas en conjunto dan cuerpo a la comunidad como entidad grupal, sus patios clónicos son los primeros elementos de contacto con la ciudad y sus fachadas posteriores como ya se ha visto es la primera referencia visual que de ellos se tiene" (Castillo, 2005).
} 
Figura $N^{\circ}$ 15: La seguridad se enfatiza en la oferta de productos cerrados que la inmobiliaria Brasa trabaja para otros segmentos del mercado más solventes.

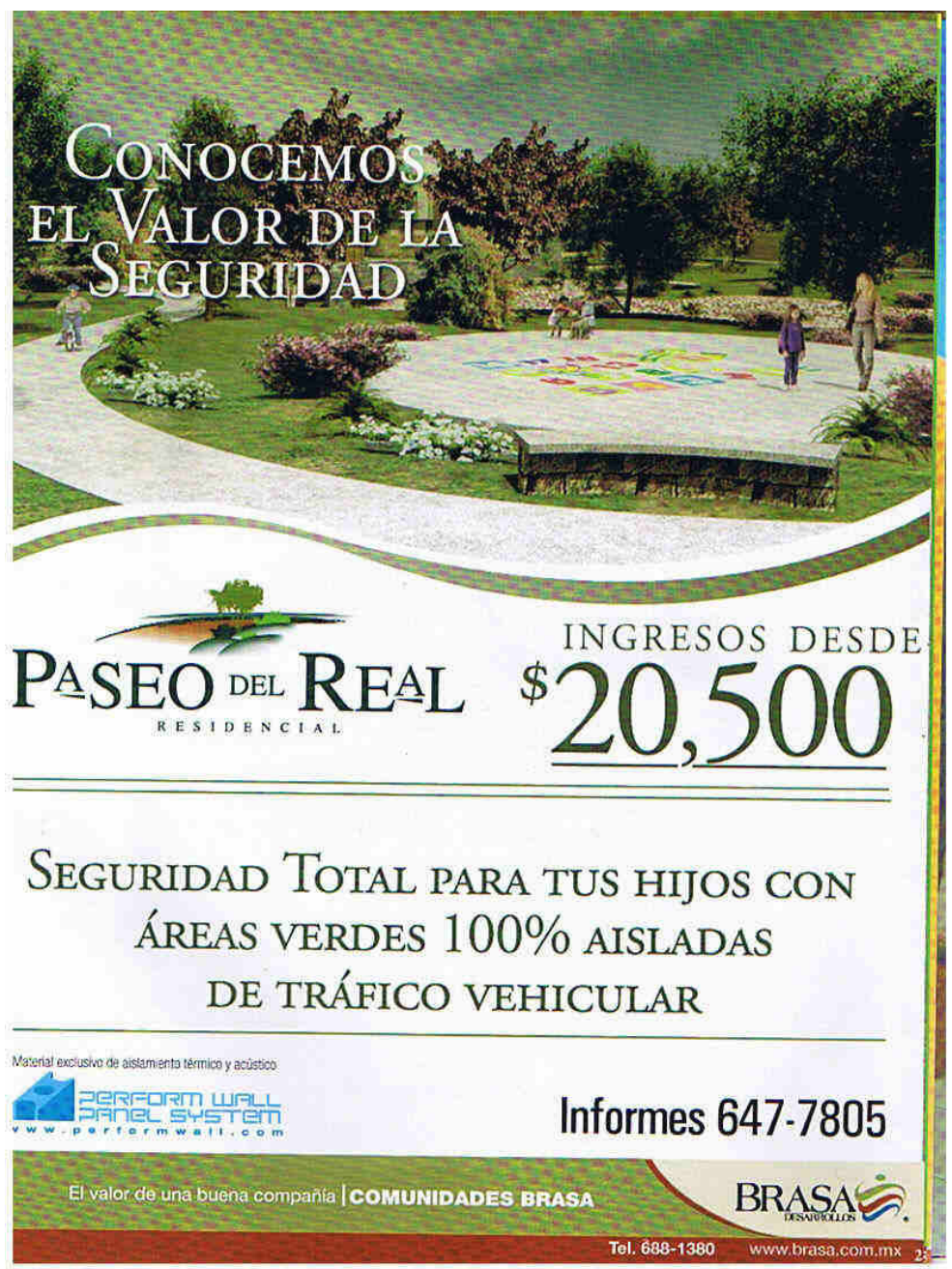

Fuente: Casas, n 3, agosto, 2005, Año 1. Publicación mensual de CANADEVI, Delegación de Chihuahua, Ciudad Juárez con registro en trámite.

En Nogales, la producción en serie de las cerradas sociales ha sido realizada, en un primer momento, por promotores locales que se especializan en este producto. Los casos de Mediterráneo I, Nuevo Milenio, Mediterráneo II y El Paseo, en el sector Poniente, son emprendidos por el empresario y propietario de suelo Héctor Monroy en asociación con el arquitecto de Hermosillo Ernesto Brau Rojas. Los tres primeros forman físicamente un conjunto pues su localización al final de la Calle Victoriano Huertas es contigua, en los polígonos catastrales J (F. Mediterráneo) y K (Nuevo Milenio con acceso a la calle citada y Mediterráneo $2^{\mathrm{a}}$ etapa, al interior) colindando con el límite del antiguo perímetro urbano y el Rancho Las Canoas. La razón de esta contigüidad es la posesión del suelo. Se trata de parte de la 
propiedad de Héctor Monroy ${ }^{61}$ que desde 1972 es dueño de 20,3 hectáreas que en 1993 el Ayuntamiento le permite subdividir en dos porciones.

Figura 16: Clonadas en Ciudad Juárez, Chihuahua, 2005.

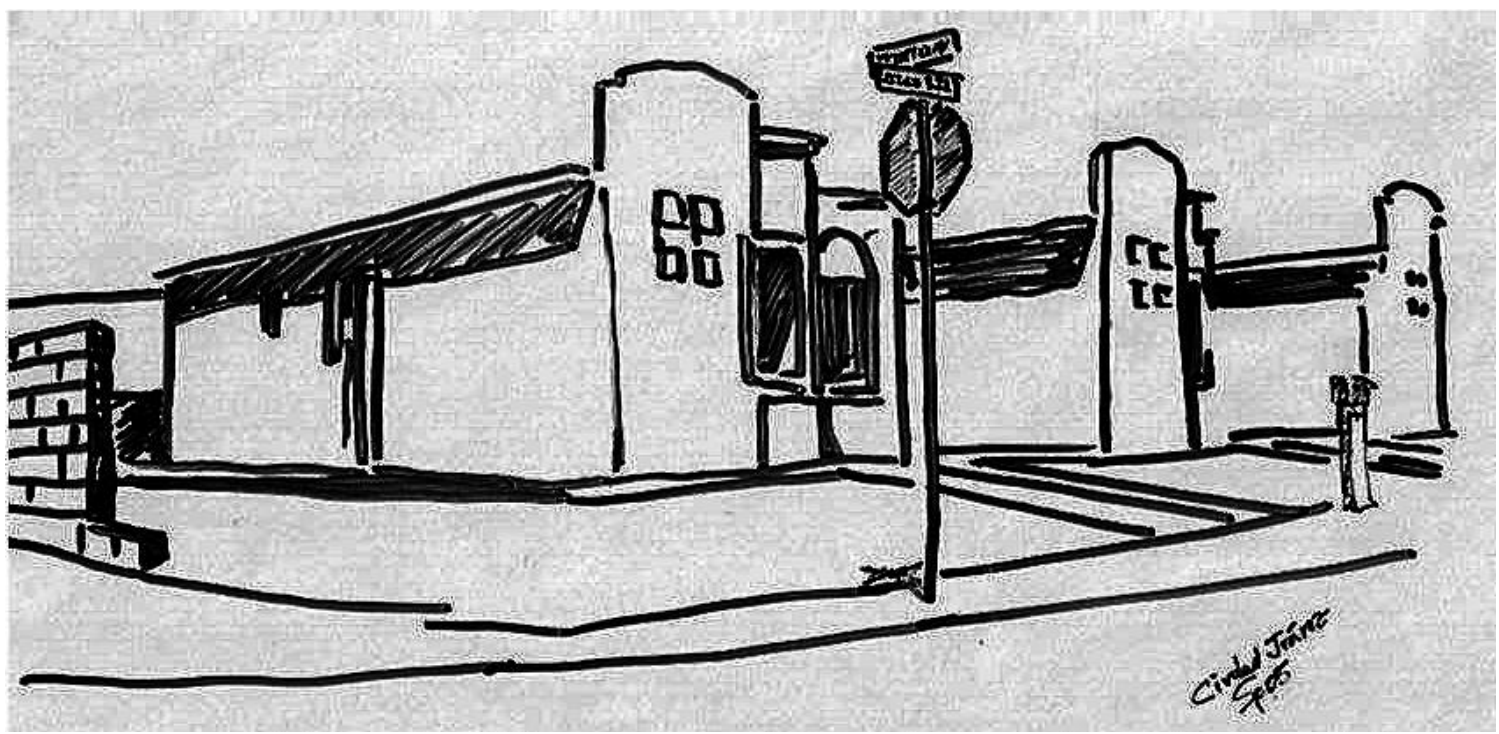

Fuente: Dibujo de la autora.

Héctor Monroy a través de su empresa y Ernesto Brau Rojas a través de Viviendas, Asesoría y Desarrollos, S A. de C. V. ${ }^{62}$ obtienen aprobación por parte del Ayuntamiento para conjuntos masivos de interés social dónde el aumento de densidades para abaratar costes de suelo, determina la adaptación a la topografía apoyada en diseños laberínticos y/o reticulares, según los casos, pero con escasas accesibilidades a la vialidad principal, sólo dos o tres accesos en agrupamientos de casitas de 20 hectáreas. La peculiaridad morfológica del conjunto radica en sus ordenaciones por sectores, "semicerrados", a modo de microambientes. Esto es, muy próximos a una organización y diseño de la traza cerrada. El Ayuntamiento señala a los promotores que deben adecuar parte del trazado propuesto "cuando por razones justificadas existan en el proyecto calles locales cerradas, éstas deberán rematar en una glorieta cuyo diámetro tendrá como mínimo dos veces el ancho del arroyo, más el ancho de las banquetas correspondientes. De lo anteriormente expuesto se requiere la adecuación o justificación para la elaboración del proyecto, en el extremo de la calle Mediterráneo (cerrada)" ${ }^{n 3}$.

El peculiar diseño con la configuración de intramanzanas, que no son otra cosa que cerradas sobre cerrada, como la Privada Atenas en la Manzana interior 6, rodeada por la 5, la Privada Venecia, envuelta parcialmente por la misma Manzana 5 y por la Manzana 8 y la Privada

\footnotetext{
${ }^{61}$ En 1972 Héctor Monroy compró al Doctor David Flores Guerra, un cirujano de Atoyac nacido en 1900, dueño del Rancho Las Canoas, 270,49 hectáreas, a su vez adquirido en 1954 al gran terrateniente de Nogales Alejandro C. Villaseñor

${ }^{62}$ Creada en Hermosillo en 1990 y constituida por 10.000 acciones de 1.000 pesos. La mitad propiedad del presidente del Consejo de administración, el arquitecto Ernesto Brau Rojas. Además forman parte de la empresa el hermano del presidente, Agustín Brau Rojas, la vocal Ma Ángeles Mendívil Estrada, la tesorera Rebeca Martínez Antúnez y el secretario Francisco Javier Mendívil Estrada, hermano de la vocal y dueño de la otra mitad de las acciones que componen el capital social de la empresa.

${ }^{63}$ Carta de la Dirección de Planeación y control del Desarrollo Urbano de 29 de octubre de 1993. Oficio no 0516-10-93, al Director General de Vivienda, Asesoría y Desarrollos, S. A. de C. V.
} 
Marruecos (o manzana 9) rodeada por la manzana 8 que al igual que la 5 tiene mucho mayor tamaño y un diseño y distribución que deja aisladas las privadas referidas.

Asimismo, es también singular la distribución de las áreas comercial, de reserva, verde y equipamiento que quedan concentrados en el sector interior del conjunto y articulado al resto por la Avenida Tiber. Por tanto, ésta y la Avenida de los Alpes fragmenta el conjunto alargado del fraccionamiento en tres sectores. El más interior de la vialidad colectora (Victoriano Huertas, luego Avenida del Tecnológico) es el que recibe las dotaciones y los otros dos, bien conectados por las vialidades locales interiores quedan reservados exclusivamente a vivienda. Al interior de estos dos sectores especializados en su uso residencial se ubican las privadas citadas. Se trata de 190 lotes que ocupan $37.636,1$ metros cuadrados de superficie al incluir un espacio comercial de 1.198,1 y un área de reserva de $2.336,5$, siendo el $37 \%$ del suelo -del total de $60.287,5-$ dedicado a equipamiento, verde y viales $(18.116,1)$. Aunque el conjunto de las dos fases de Mediterráneo ${ }^{64}$ serán 398 lotes $^{65}$.

Figura Na 17: Santa Lucía, en San Carlos, Nogales, Sonora, 2003.

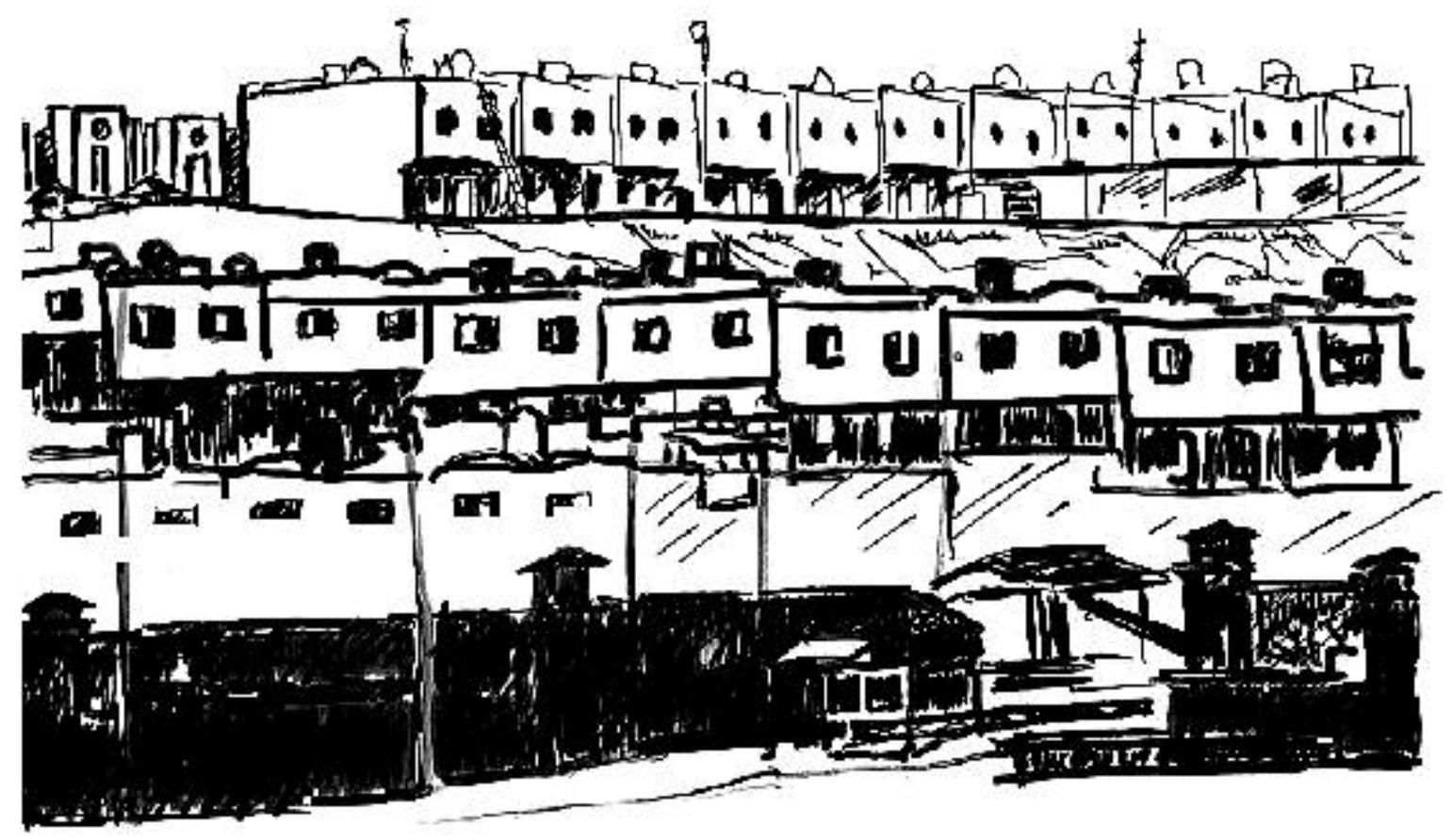

Fuente: Dibujo de la autora.

\footnotetext{
${ }^{64}$ Es sobre la menor de estas porciones de terreno, la de 60.287,5 metros cuadrados, que promueve el fraccionamiento Mediterráneo a partir de la concesión de licencia de uso del suelo: "el uso para el predio que nos ocupa es Residencial para Vivienda de Interés Social" (Convenio de autorización del Fraccionamiento Mediterráneo). No deja de ser llamativo el hecho de que consigue la licencia de uso del suelo antes que la de subdivisión anterior. Oficio nº 002/04/9il de 1993 y oficio $n^{\circ}$ 0032/06/93 el de subdivisión, de 11 de junio de 1993.

65 Ocupan 204.193 metros cuadrados de superficie a razón de 6 habitantes por lote con lo que la operación se estima sirva para el alojamiento de 2.360 habitantes. El tamaño de los lotes no experimenta cambios significativos entre unas y otras manzanas según su ubicación, siendo lo más frecuente superficies de lotes entre los 160 y los 300 metros cuadrados. Se trata de viviendas duplex, con dos viviendas en cada lote y algún caso de triples.
} 
La segunda etapa del Fraccionamiento Mediterráneo es promovida a partir de $1999^{66}$ fecha del convenio de autorización y de la de factibilidad de uso del suelo a Héctor Monroy para fraccionamiento de interés social.

El diseño y organización del Fraccionamiento Mediterráneo Segunda Etapa está concebido, en una composición del tipo muñecas rusas, con varias cerradas al interior de las cerradas envolventes, cómo Cerrada Montecarlo. Preparadas para ser cerradas en cualquier momento por vecinos que sientan la necesidad de encerrarse-. El mismo año de 1999 ya se obtuvieron todos los permisos necesarios de anteproyecto de lotificación aprobado, de agua potable, alcantarillado, electrificación, alumbrado público y licencia de uso del suelo. Se les precisó que "quedan también incluidas -entre las obras de urbanización a cargo de la promotora- las obras necesarias de urbanización para la liga del fraccionamiento que nos ocupa con el resto de la zona urbana"67. Si se realiza la citada conexión, al menos en el plano del proyecto presentado para la relotificación, con la primera fase del fraccionamiento a través de las Calles Mónaco y Gibraltar.

Es posible que sea la primera ocasión que en la tramitación de los fraccionamientos se incluya una cláusula que destaca por lo que significa de control del proceso de producción y de supervisión de la obra privada. Una garantía para el erario público ante la producción de ciudad por los intereses privados: "para que el Ayuntamiento pueda recibir en forma material y jurídica el fraccionamiento, el fraccionador deberá comprobar la enajenación, por lo menos, del $80 \%$ de los lotes" "68. Desde el 2000 hay constancia oficial de que se van solicitando al Ayuntamiento, cómo indica la cláusula quinta del Convenio, la licencia de construcción para edificar por grupos de 50 viviendas.

Otro caso de fraccionamiento de interés social, sobre los mismos terrenos de Héctor Monroy, es el Fraccionamiento Nuevo Milenio. El primer dato relevante es la mediación de una nueva empresa, Marvil Corporation, S. A. de C. V. creada en 1996 con 200.000 pesos de capital social y propiedad de Héctor Monroy ${ }^{69}$, claramente especializada en el sector inmobiliario, según se desprende de la larga descripción de su objeto social, y sin la intervención de las empresas del arquitecto Brau Rojas. La promoción se realiza sobre 10 hectáreas de las que resultan 57.094 metros cuadrados para área habitacional con 370 lotes que se emprenden por fases a partir de la aprobación del Convenio del Fraccionamiento en $1999^{70}$, mismo año que se solicitan y consiguen todas las licencias y permisos pertinentes. Las viviendas a construir son duplex, triples y cuádruples, es decir, de dos a cuatro viviendas por lote, siendo el lote tipo de 10 por 15 con muro medianero común, perfecto ejemplo de vivienda de interés social. En abril del 2003 había constancia, en el archivo del Ayuntamiento, de 150 viviendas dentro de la denominada Línea III de Infonavit, con planos y proyecto de 2001 y referenciada como

\footnotetext{
${ }^{66}$ Resultan 29.249 metros cuadrados cómo área vendible y habitacional y bastante suelo comercial $(5.999,6)$, también vendible, junto con los 4.334,5 de donación, 80,2 de área verde y los 17.365,8 para vía pública. En 2001 es relotificada por la otra empresa de Ernesto Brau Rojas, Diseño e Ingeniería Vértice, S. A. de C. V. Resulta un número menor de lotes (160), menor superficie habitacional, mucha menos comercial $(2.317,6)$ y de donación (1.583), con unos porcentajes no frecuentes inferiores al $6 \%$ de la superficie vendible, también aplicable a la vialidad, en este caso con la desproporción del $25 \%$

${ }^{67}$ Cláusula 5 del Convenio de autorización del fraccionamiento que remite al Art. 102, 106 Fl y 141 FII de la Ley 101 de Desarrollo Urbano del Estado de Sonora.

${ }_{68}$ Cláusula 10 del Convenio de autorización del fraccionamiento.

69 La composición familiar de otros miembros del consejo de administración demuestra su escasa participación accionarial. Es la familia Maldonado Carrillo -hermanos e ingenieros José Héctor y Rosario, de Sinaloa-, y el ingeniero también Francisco Javier Maldonado Vázquez de Hermosillo. Tiene la misma dirección social que las empresas anteriores de Héctor Monroy.

${ }^{70}$ Hay una modificación del Convenio en junio de 2000. El dato adicional de mayor interés es la participación de una nueva empresa Infraestructura SINTECK del arquitecto Arnoldo García Rodríguez que desde 1998 tramita los permisos de petición de licencia de construcción, lo que no deja de ser una paradoja pues el convenio del fraccionamiento es de 1999.
} 
"Sección Loma Bonita 1" y una anterior, escasamente documentada de 100 viviendas de 64 metros cuadrados y dos alturas en planta.

Estos ensayos aún no se corresponden con las más exitosas en otras ciudades de la frontera y del país de 30 metros cuadrados y con la siguiente categoría de 40 metros cuadrados. Para las primeras los créditos otorgados por el gobierno son de casi el 100\% para familias con ingresos inferiores a 1,5 salarios mínimos, por debajo de 100 pesos diarios, las llaman "unidades básicas de viviendas y no casas" y cuestan alrededor de 80.000 pesos (La Revista, 2005: 28). Por el Norte crecen, se multiplican en Hermosillo, en Tijuana, allí "en los estados fronterizos, por ejemplo, primero se anotan en una lista, y cuando ya está listo el lote, entregan el enganche" (La Revista, 2005).

Las nuevas cerradas de interés social: "los cuartitos de Fox" ya han llegado a la frontera. La empresa Supervisión Integral, S. A. de C. V. es la promotora del Fraccionamiento Las Bellotas, una inmobiliaria de Hermosillo creada en 1995 de la que forma parte Ernesto Verdugo Garza, como apoderado desde 2001, pero dueño de los terrenos de 146,25 hectáreas desde $1977^{71}$. El plano de parcelación muestra la gran extensión a desarrollar, el gran vacío intermedio con respecto a la ciudad, la desarticulación respecto a la arteria colectora mayor, la Calzada del Raquet al sur -que no tiene ninguna comunicación con el citado fraccionamiento- y la Carretera Internacional, desde la que parte un acceso a las dos etapas construidas entre el Parque Industria San Ramón al Norte y el del Cid al sur hasta 2003.

Es un ejemplo elocuente de la desarticulación con la que se están construyendo las periferias y de la magnitud de las operaciones a partir de 2000-2001 cuándo se inician las gestiones y obras de otras fases del Fraccionamiento gemelo de San Carlos (Figura $N^{\circ} 17$ ). Estos nuevos modos de "hacer ciudad" muestran la irrupción de nuevos agentes, concretamente la penetración de otros agentes externos, normalmente estableciendo alguna vinculación con el poder local ,y el aumento de escala de las operaciones. Este binomio promotor-operación, y los cambios en el producto y en la envergadura de la inversión que conllevan, es algo común en el sector inmobiliario internacional. Por ejemplo, la sección denominada Santa Lucia, se compone en la actualidad de casi 5000 viviendas, tras tres etapas, a base de entregas de 150 a 200 viviendas duplex a séxtuples ${ }^{72}$.

Un último ejemplo para cerrr la producción masiva y clónica de vivienda, plenamente fordista, es el caso de la segunda fase de Las Bellotas. Sobre 65.354 metros cuadrados emprenden la segunda fase con la Sección Las Nueces, compuesta de 214 lotes que los permisos oficiales aprueban en 2001. La intención del promotor, una corporación compuesta de diversas empresas foráneas ${ }^{73}$, es fraccionar el conjunto de las 146 hectáreas del predio Las Bellotas y así se contempla ya en el Convenio: Queda acordado por ambas partes que la superficie de 20.000 metros cuadrados será considerada cómo área de donación total para los futuros desarrollos, y que dentro de esta superficie total se incluye una porción de 4.456,2 hectáreas que la fraccionadora cederá cómo área de donación correspondiente a la segunda etapa del citado fraccionamiento" ${ }^{\prime 4}$.

El plano de lotificación de este sector muestra la opción morfológica más racionalista que toman las cerradas de interés social tendentes a la reproducción de tramas reticulares que

\footnotetext{
${ }^{71}$ Práctica muy común de los inversores capitalistas foráneos en cualquier sistema inmobiliario local. Se producen alianzas entre el inversor externo y el propietario local.

${ }^{72}$ Edificaciones Modernas de Sonora es la promotora del Fraccionamiento que ha experimentado cinco modificaciones desde 1994 fecha en la que se aprueba el Convenio, presumiblemente para ir adaptándose a las condiciones del mercado, tanto residencial cómo del financiero-hipotecario.

${ }_{73}$ Supervisión Integral, Desarrollos del Norte Cenit, Desarrollos Hemerson (1925, Hermosillo), Desarrollos Gimsel. Expedientes del Fraccionamiento Las Bellotas. DGDU de Nogales.

${ }^{74}$ Boletín Oficial del jueves 9 de agosto de 2001, n 12 , sección III.
} 
facilitan la lotificación. En este caso cinco calles paralelas permiten obtener manzanas de 30 lotes entre las calles Cipreses, Encinos, Fresnos, Jacarandas y Álamos, y se articulan con una avenida mayor, acceso al conjunto, llamada de los Olivos, los remates de la irregular de la finca matriz se resuelven con la aparición de nuevo de trazados reticulares más recogidos formando las calles Cerrada del Pino y Cerrada de los Sauces.

\section{A modo de conclusión}

Las conclusiones tentativas que se han ido obteniendo de este artículo permiten extraer como propuesta final que se hace necesario un análisis histórico de los patrones y modelos de la vivienda social, ineludiblemente, en clave interdisciplinaria y de carácter comparativo. Aquí se han esbozado algunas de esas múltiples relaciones cruzadas para enfrentarlo.

\section{Fuentes y bibliografía citada}

RIVIÈRE, H. Empresarios y globalización en la frontera norte, In ALBA, C. -AZIZ, A. (Coord.) Desarrollo Y política en la frontera norte, México: CIESAS:IRD:UACJ, p. 39-92, 2000.

BAUMAN, Z. La sociedad sitiada. Buenos Aires: FCE, 2004.

BORDIEU, P. Las estructuras sociales de la economía, Barcelona: Editorial Anagrama, 282 p., 2000), 2003.

CASTILLO, S. Comunidades cerradas. [En línea] http://docentes.uacj.mx/museodigital/teoria/LAV/sergiocas/, 2005.

CERVANTES, J.; MAYA, E. La habitabilidad en megaconjuntos habitacionales. Conjunto San Buenaventura, Ixtapaluca, In GREENE, F. (Coord.) Urbanismo y vivienda, México: Universidad Nacional Autónoma de México-Posgrado de Urbanismo, p. 358-369, 2005.

CHAVES, N. El diseño invisible. Siete lecciones sobre la intervención culta en el hábitat humano, Buenos Aires: Paidós, 2005.

CHAVÉZ, E. Los conjuntos urbanos como alternativa de cambio social, In GREENE, F. (Coord.) Urbanismo y vivienda, México: Universidad Nacional Autónoma de México-Posgrado de Urbanismo, p. 377-385, 2005.

EL KILO. Órgano de difusión interior de Urbi Desarrollos Urbanos, 2005, año 3, nº 9, eneroabril. 2000 ejemplares.

ESQUIVEL, M. T. Los habitantes de San Buenaventura: uso y apropiación del entorno, In MAYA, E.; CERVANTES, J. (Coord.) La producción de vivienda del sector privado y su problemática en el municipio de Ixtapaluca, México: Plaza y Valdés Editores, p. 51-74, 2005.

ESQUIVEL, M. T.; MAYA, E.; CERVANTES, J. La promoción privada y los grandes conjuntos habitacionales: nuevas modalidades de acceso a la vivienda. Scripta Nova. Revista electrónica de geografía y ciencias sociales. Barcelona: Universidad de Barcelona, 1 de agosto de 2005, vol. IX, núm. 194 (21). http://www.ub.es/geocrit/sn/sn-194-21.htm

EZQUIAGA, J. M. El proyecto del alojamiento: criterios de diseño, In TARCHÓPULOS, D. (Ed.) Vivienda social. Miradas actuales a retos recientes, Bogotá: Editorial Pontificia Universidad Javeriana, 2003.

GARCÍA, M. L. La producción social del habitat popular. La articulación existente entre el capital de la gente y la miseria del capital, In GREENE, F. (Coord.) Urbanismo y vivienda, México: Universidad Nacional Autónoma de México-Posgrado de Urbanismo, p. 405-411, 2005. HIDALGO, R. La vivienda social en Chile y la construcción del espacio urbano en el Santiago del siglo XX, Santiago de Chile: Instituto de Geografía, Pontificia Universidad Católica de ChileCentro de Investigaciones Diego Barros, 2004.

HIERNAUX, D. Paisajes fugaces y geografías efímeras en la metrópolis contemporánea. In NOGUÉ, J. Paisatges incògnits, territoris ocults: les geografies de la invisibilitat. Olot: III Seminari Internacional sobre Paisatge, 2002. 
MARTíNEZ, A.; MATOS, B. Bien vivido Mr. Marshall, In SAMBRICIO, C. (Ed.) Un siglo de vivienda social, 103-2003, Madrid: Ayuntamiento de Madrid-Ministerio de Fomento-Centenario del Instituto de Reformas Sociales, 2 Tomos, pp. 360-371, Tomo II, 2003.

MAS, R.; RODRÍGUEZ, I. Propiedad urbana, promoción inmueble y Catastro en el Madrid de hoy, Catastro, no 21, p. 54-63., 1994.

MAS, R.; RODRÍGUEZ, I. El mercado inmobiliario en España, In CAPEL, H. Ciudades, arquitectura y espacio urbano, Almería: Instituto Cajamar, Col. Mediterráneo económico, $n^{\circ} 3$, p. 170-199, 2003.

MAYA, E.; CERVANTES, J. Los desarrollos habitacionales y su impacto en la planeación metropolitana del Valle de México, In GREENE, F. (Coord.) Urbanismo y vivienda, México: Universidad Nacional Autónoma de México-Posgrado de Urbanismo, p. 370-376, 2005.

MAYCOTT, E. Nuevas tipologías de vivienda de interés social financiadas por programas gubernamentales. El caso de la vivienda económica en Ciudad Juárez, Chih., XXVIII RNIU. Dilemas de la Sociedad Fronteriza. Ciudad Juárez: [En línea] http://www.uacj.mx/ICSA/Investiga/RNIU/default.htm, 2005.

MAYCOTT, E. Espacios públicos: una extensión de la vivienda mínima y Pérdida de espacio público ante la presencia de conjuntos habitacionales en régimen de condominio, In GREENE, F. (Coord.) Urbanismo y vivienda, México: Universidad Nacional Autónoma de MéxicoPosgrado de Urbanismo, p. 334-345 y 386-395, 2005.

MÉNDEZ, E. Arquitectura transitoria. Hermosillo: El Colegio de Sonora-Itesca-Itesm/Unidad Sonora Norte, 2002.

MÉNDEZ, E.; RODRÍGUEZ, I. Urbanismo cerrado. La fórmula versátil y ubicua de la globalidad. El caso de las comunidades cerradas de la frontera noroeste mexicana, In CASTILLO, R. J. Actas de las VII(I) y VIII (II). Reuniones internacionales La Frontera: una nueva concepción cultural, Bogotá: Universidad Piloto de Colombia, pp. 69-75, 2004.

MÉNDEZ, E.; LÓPEZ, L.; RODRÍGUEZ, I. Simulación: vecindarios defensivos, dispositivo ambivalente de seguridad, Ciudades, Revista Red Nacional de Investigación Urbana, Dilemas de la sociedad fronteriza, $n^{\circ} 69$, p. 41-48, 2006.

MUÑÓZ, F. Paisajes aterritoriales, paisajes en huelga. In III SEMINARI INTERNACIONAL SOBRE PAISATGE. Paisatges incògnits, territoris ocults: les geografies de la invisibilitat. Olot: Universitat de Girona, Observatori del Paisatge. CUIMPB,20-2 de octubre 2005. [En línea] http://www.catpaisatge.net-observatoriatpaisatge.net

ORDÓÑEZ, J.F.; LICONA, J.M. El programa Habitat y la vivienda, In GREENE, F. (Coord.) Urbanismo y vivienda, México: Universidad Nacional Autónoma de México-Posgrado de Urbanismo, p. 532-538, 2005.

PLAN MAESTRO COMUNITARIO. Urbi Desarrollos Urbanos (documento interno), 2005.

RAYA, E. Indicadores de exclusión social, Bilbao: Universidad del País Vasco-Servicio Editorial, 2006.

$\mathrm{ROCH}, \mathrm{F}$. El sector privado y la construcción de viviendas sociales, In SAMBRICIO, C. (Ed.) Un siglo de vivienda social, 103-2003, Madrid: Ayuntamiento de Madrid-Ministerio de FomentoCentenario del Instituto de Reformas Sociales, 2 Tomos, pp. 170-173, Tomo II, 2003.

RODRÍGUEZ, I. Las inmobiliarias madrileñas, II Congreso Mundial Vasco, Vitoria-Gasteiz: Servicio Central de Publicaciones del Gobierno Vasco, pp. 393-401, 1988.

RODRÍGUEZ, I. La promoción inmobiliaria reciente, In RODRÍGUEZ, I. La promoción privada de viviendas en Madrid. Caseros e Inmobiliarias, Tesis Doctoral, Madrid, Universidad Autónoma de Madrid, 3 vol., 1998.

RODRÍGUEZ, I. Vivienda y promoción inmobiliaria en Madrid, Lleida: Servei de PublicacionsUniversitat de Lleida, espai-temps, 43, 2001.

RODRÍGUEZ, I. Urbanizaciones cerradas en Latinoamérica", en Ciudad y Territorio-Estudios Territoriales, Madrid, Ministerio de Fomento, XXXIV, 133-134, pp. 459-472, 2002.

RODRÍGUEZ, I. ¿'Privatopia' versus ciudad pública? La materialización del miedo en el espacio urbano", en Gutiérrez, O. (Coord.) La ciudad y el miedo, Girona: Universitat de Girona-AGEGGU, pp. 127-152, 2005a. 
RODRÍGUEZ, I. La reconquista de la ciudad inmanejable", Imaginales, $\mathrm{n}^{\circ}$ 2, pp. 81-110, 2005b. RODRÍGUEZ, I. La urbanización cerrada en Latinoamérica, In PONCE, G. La ciudad fragmentada. Nuevas formas de habitat. Alicante: Publicaciones-Universidad de Alicante, 2006. RODRÍGUEZ, I.; MÉNDEZ, E.; LÓPEZ, L. Espacio urbano, exclusión y frontera norte de México, Madrid: Universidad Autónoma de Madrid, Servicio de Publicaciones, 2006.

SAMBRICIO, C. La normalización de lo vernáculo, In SAMBRICIO, C. (Ed.) Un siglo de vivienda social, 103-2003, Madrid: Ayuntamiento de Madrid-Ministerio de Fomento-Centenario del Instituto de Reformas Sociales, 2 Tomos, pp. 72-75, Tomo I, 2003.

SAMBRICIO, C. Urbis, In SAMBRICIO, C. (Ed.) Un siglo de vivienda social, 103-2003, Madrid: Ayuntamiento de Madrid-Ministerio de Fomento-Centenario del Instituto de Reformas Sociales, 2 Tomos, p. 268-270, Tomo I, 2003.

TARCHÓPULOS, D.; CEBALLOS, O.L. Calidad de la vivienda dirigida a sectores bajos ingresos en Bogotá, Bogotá: Editorial Pontificia Universidad Javeriana, 2003.

TARCHÓPULOS, D.; CEBALLOS, O.L. Patrones urbanísticos y arquitectónicos en la vivienda dirigida a sectores de bajos ingresos en Bogotá, Bogotá: Editorial Pontificia Universidad Javeriana, 2005.

VILAGRASA, J. El estudio de la morfología urbana. Geocrítica, 1991, nº 92, marzo. 